\title{
Conservation Options for Private Landowners in Florida ${ }^{1}$
}

\author{
Martin B. Main, Annisa Karim, and Mark E. Hostetler ${ }^{2}$

\section{Introduction}

Florida is one of the fastest growing states and included 11 of the 100 fastest growing counties in the United States during 2003. Consequently, natural and agricultural lands are in high demand as the pressure to convert these areas to residential and/or commercial uses continues to increase. There are many compelling reasons, however, to conserve natural and agricultural lands in Florida. These include issues related to quality of life, traditional rural lifestyles, aesthetic values, significant economic contributions to the state, and even national food supply. Private lands also play a crucial role in the conservation of wildlife populations in Florida.

Economic decisions strongly influence land use decisions. But personal values also influence how private landowners make decisions on their own land. Many landowners realize the strong ecological or agricultural value of their land and wish to legally protect it from being converted or zoned for other purposes. Broad arrays of options are available for private landowners facing these decisions, although locating the source of information on these options can be time consuming and frustrating.
The objective of this document is to explain the principal land conservation options available to landowners and to provide contact information for organizations in Florida that partner in these efforts. Actual contact and negotiated agreements are left to the landowners, their legal and financial advisors, and the partner organizations.

\section{Conservation Easements}

\section{Land Conservation Options}

\section{Easements}

An easement is a right of use over the property of another. A landowner granting an easement gives up, permanently or for a period of time, certain rights regarding ownership of his or her property. For example, a landowner may grant an easement to accommodate a neighbor to have right of way over his land so the neighbor may access his property. Easements are not a new concept. Utility companies and government agencies acquire easements to deliver services essential to the community or public, such as pipelines for water or gas, power lines, communications cables, and roadways.

1. This document, Circular 1441, is one of a series of the Department of Wildlife Ecology and Conservation, Florida Cooperative Extension Service, Institute of Food and Agricultural Sciences, University of Florida. Original publication date: April 2003. Visit the EDIS Web site at http://edis.ifas.ufl.edu.

2. Martin B. Main, Associate Professor, University of Florida, Southwest Florida Research and Education Center, Immokalee, FL; Mark E. Hostetler, Assistant Professor, University of Florida, Wildlife Ecology and Conservation Department, Gainesville, FL; and Annisa Karim, Research Assistant, University of Florida, Southwest Florida Research and Education Center, Immokalee, FL.

The Institute of Food and Agricultural Sciences is an equal opportunity/affirmative action employer authorized to provide research, educational information and other services only to individuals and institutions that function without regard to race, color, sex, age, handicap, or national origin. For information on obtaining other extension publications, contact your county Cooperative Extension Service office. Florida Cooperative Extension Service/Institute of Food and Agricultural Sciences/University of Florida/Christine Taylor Waddill, Dean. 


\section{Conservation Easements}

A conservation easement is a legal agreement to limit the amount of development on a property. Essentially, a conservation easement is an agreement between a landowner and a land trust, government agency, or other entity that maintains land in agricultural and/or natural uses to protect the owner's agricultural and/or conservation interests. Private landowners may wish to consider donating or selling some of these rights. These decisions may be economic, personal, or both.

Conservation easements offer great flexibility. Each conservation easement is unique and typically customized in consultations between the landowner and the partner organization. It is a legal agreement designed to consider both the landowner's needs and the conservation objectives. For example, conservation easements may be designed to allow continued farming or ranching activities, hunting, and other recreational uses. An easement might apply to just a portion of the property. In most cases, conservation easements are perpetual, so any land use restrictions remain if the land is sold or passed on to heirs. Typically, these future development rights are restricted and are recorded on the deed.

Conservation easement programs are developed and run by federal, state, and local governmental agencies as well as non-governmental organizations (NGOs). Although conservation easements are essentially similar in principle, different organizations may have different priorities depending upon their mission, and these priorities will influence the type and degree of land use restrictions required in the easement. For example, some organizations may prioritize the protection of large natural areas, while the goal of others may be to maintain agricultural lands in production.

\section{What are advantages of placing land in a conservation easement?}

Various types of financial benefits are available with conservation easements. Easements may result in direct payments, tax relief, and reduction of estate taxes when passing land to heirs.
A conservation easement also provides assurance that the land will be managed according to the wishes of the original landowner. As a legal contract that is inherited or sold with the land, a perpetual conservation easement can provide a legal instrument that prevents the land from being used in ways contrary to the interests of the owner, even if sold or after the owner's death.

Four potential tax savings are associated with donating a conservation easement: income tax, real property tax, federal gift and estate tax, and an estate tax exclusion (from Harrison and Richardson, Purdue University). For all of the below options, please check with a qualified tax advisor.

\section{Potential Income Tax Savings:}

Gifts of all or part of a qualified conservation easement provide a charitable income tax deduction. An annual deduction is limited to $30 \%$ of the donor's adjusted gross income. If the donor cannot use the whole deduction in the year of the gift, he or she may deduct a portion of a current gift in each of the next five years. Each year is still limited to the $30 \%$ deduction. For example, say a landowner's fair market value of a donated conservation easement is $\$ 200,000$. If the landowner has an adjusted gross income of $\$ 80,000$, then the charitable deduction for the year of the transfer is $\$ 24,000$ (30\% x $\$ 80,000)$. This leaves $\$ 176,000(\$ 200,000$ - $\$ 24,000)$ to carryover; over the next 5 years, $\$ 120,000$ of the $\$ 176,000$ (5 years $x \$ 24,000 /$ year $=\$ 120,000)$. Thus, the total contribution is not tax deductible. Taxpayers can make donations over several years to overcome the annual charitable deduction limitation.

\section{Real Property Tax Savings:}

Because the market value of land is reduced after granting a conservation easement, a real property tax savings may result. This depends on the type of land on which the conservation easement is being placed. For example, if the land has a zoning of one unit per 5 acres, a conservation easement may restrict future development of these units. Thus, a new property tax assessment may be lower. The landowner pays less property tax. 


\section{Federal Gift \& Estate Tax Savings:}

Conservation easements may be transferred to the appropriate charitable or government entity free of federal gift and estate taxes. The federal unified gift and estate transfer tax is based on the fair market value of property on the date of the lifetime gift or on the date of death. Qualified charitable transfers are exempt from federal gift or estate transfer tax. Thus, land in a deceased's estate is reduced in value by the value of a conservation easement. Therefore, less gift or estate transfer tax is assessed on the land. Again, check with a tax advisor about this option.

\section{Estate Tax Exclusion for Qualified} Conservation Easements:

A federal estate tax provision allows land that is qualified as a conservation easement (QCE) to be excluded from the total land value of a deceased's estate. With a QCE, as much as $40 \%$ (or the actual percentage) of the land value may be excluded from the federal estate tax estate. This exclusion applies after the value of the conservation easement is subtracted from the fair market value of the land.

The QCE may be on any land in the United States. The maximum amount that can be excluded is the lesser of the "applicable percentage" (40\% max.) or an "exclusion limit" (\$500,000 in 2002 and thereafter). Again, the percentage exclusion may be as high as $40 \%$, but it is reduced by two percentage points for each percentage point (or fraction thereof) by which the value of the qualified conservation easement is less than $30 \%$ of the value of the land. Here, the value of the land is determined without regard to the value of the easement. A QCE should not be valued at $10 \%$ or less of the value of the land (before the easement is made). If the QCE is less than $10 \%$, tax exclusion is not possible for the property.

To illustrate, consider a property that is passed on to heirs and has a QCE. The fair market value of the land on the date of death before considering the conservation easement is $\$ 1,000,000$. The value of the QCE is $\$ 250,000$. First of all, the $\$ 250,000$ of the QCE is fully deductible from the estate tax estate. Because $\$ 250,000$ equals $25 \%$ of $\$ 1$ million, which is less than $30 \%$, one takes away two percentage points for each of the five percentage points difference (30 $-25)$. This gives us a $10 \%$ reduction in the applicable percentage. The applicable percentage is reduced to $30 \%$ (40-10). The conservation easement's tax exclusion is $\$ 225,000$ (30\% of $\$ 750,000)$.

To meet the criteria for a "qualified conservation easement," certain requirements must be satisfied. First, the easement must restrict the use of the property in perpetuity. Second, the easement must be made to a "qualified organization." A qualified organization may be a government entity or a public foundation that is organized for the specific purposes of conservation. The organization must have a commitment to maintain the easement's conservation purpose and the resources to enforce restrictions on that land. Third, the easement must serve one or more of the following:

- The preservation of land for outdoor recreation by or the education of the general public.

- The protection of relatively natural habitat of fish, wildlife or plants, or a similar ecosystem.

- The preservation of open space, including farmland and forestland.

\section{What are disadvantages of placing land in an easement?}

Conservation easements restrict development options. Consequently, easements may reduce market value of the land.

More information regarding the Florida state statute on conservation easements can be found online at http://www.flsenate.gov/Statutes/index.cfm (Florida State Statute 704.06, Title XL, Chapter 704).

\section{Land Donations}

The donation of land to a qualified public agency, land trust, or nonprofit organization as a charitable gift is an option that can be used to eliminate taxes associated with some or all of their holdings. Land donations may be an attractive option for landowners who: 1) do not intend to pass land to heirs; 2) possess land they no longer wish to manage; 3 ) own highly appreciated property that poses a tax 
burden; and/or 4) have substantial real estate holdings and wish to reduce estate tax burdens.

When considering a land donation, several options exist that a private landowner should consider in consultation with a legal and/or financial advisor. We outline several of these below.

\section{Immediate Donation}

An immediate donation is simply the voluntary donation of all or portions of a landowner's property to a qualified public agency, land trust, or nonprofit organization. After the donation is made, the landowner is not responsible for costs, maintenance, or uses associated with the property.

\section{Donating a Remainder Interest in}

\section{Land/Reserved Life Estate}

A donation with a reserved life estate occurs when a landowner agrees to donate property to a qualified land trust, public agency, or nonprofit organization, but reserves use of the property until he or she dies. Under this option, the landowner may continue to live and work on the land and may be eligible for an income tax deduction when the gift is made. Until the land is transferred into the ownership of the partner organization, the donor is fully responsible for taxes, insurance, maintenance, leasing, and any other costs associated with managing the land. When the last legally entitled survivor dies, the agency or organization takes ownership. The agency or organization can keep the property or sell it. The land is sometimes subject to a transaction.

\section{Donation with a Charitable Remainder Trust}

This option may be attractive for highly appreciated land, the sale of which would incur high capital gains tax. In situations where a landowner may not be able to afford to make an outright donation, a charitable remainder unitrust may be considered. This option requires that the property first be placed in a conservation easement and then be placed in a trust. The trustee will then sell the land. The net proceeds from the sale are then invested by the trustee, and the income is paid to the donor or the beneficiaries specified by the donor. This income allows the donor (or beneficiaries) to receive payments each year for a fixed term or for life. Upon the death of the donor, the principal of the trust is distributed to a qualified land trust, public agency, or nonprofit organization. The gift often qualifies for a charitable income tax deduction when the land is placed in the trust, based on the value of the land less the expected value of the payments. The transaction is complex and requires the assistance of tax counsel.

\section{Donating Land by Will (by Bequest)}

This option also is useful for highly appreciated land, the sale of which would incur high capital gains tax. This option should be considered in cases where a private landowner wants to own and control his or her land during a lifetime and ensure the protection of certain resource values following his or her death. A donation by will or bequest occurs when a landowner agrees to donate property to a qualified land trust, public agency, or organization upon his or her death. It is customary to discuss such arrangements before the original landowner's will is finalized, or at least to notify the recipient organization of its inclusion in the will. Landowners should ensure that the chosen recipient is willing and able to receive the gift. In some cases, property owners may choose to include this option in their will as a temporary measure while exploring other tools for retaining the land's ecological and/or agricultural resource values.

\section{Donations Using a Charitable Gift Annuity}

This option may be attractive to landowners who need to receive income during their lifetime and own land they would like to protect after their death. The landowner may donate the land to a qualified land trust, public agency, or other entity using a charitable gift annuity. In a charitable gift annuity, a landowner agrees to transfer certain property to the charity, and the charity agrees to make regular annuity payments to the donor (or donor-specified beneficiaries) for life. This gift of land usually qualifies for a charitable income tax deduction at the time of the gift, based on the value of the land less the expected value of the annuity payments.

\section{What are the advantages of donating land?}


The donation of land, as opposed to an outright sale, ensures that the landowner's ecological and/or agricultural values, as they relate to the land, are maintained. Donating land also releases the landowner from the responsibility of managing the land. In some cases, donations entitle donors to an income tax deduction and reduce federal estate (inheritance) taxes. Estate taxes, which are paid on the value of an individual's assets at death, are often higher than expected due to soaring land prices in many areas of Florida.

\section{What are the disadvantages of donating land?}

Donations are a charitable act. Even though the donor may receive relief from income and estate taxes, greater financial returns would likely be earned through an outright sale of the property.

\section{Bargain Sale/ Charitable Sale of Land}

This option may be attractive to private landowners that need immediate income from selling land but want the property to be maintained or managed by a qualified land trust, public agency, or other entity in a manner that respects their land use values. In a bargain sale or charitable sale of land, a portion of the value of the land is sold, and a portion is donated. The relative proportions of the sale and the donation are determined through negotiation between buyer and seller. The landowner is able to take a charitable deduction determined by the difference between the sale price of the land and its appraised fair market value.

\section{What are the advantages of a bargain or} charitable sale of land?

The financial benefits of this option come from the savings from the charitable income tax deductions received from the sale and the potential savings on capital gains taxes.

\section{What are the disadvantages of a bargain or charitable sale of land?}

The outright sale of the land may be more profitable than a charitable sale.
Disclaimer: The material in this publication is intended for general education. Individuals, businesses, and government entities that have legal or tax-related questions should consult their legal counsel or other specialists and references for assistance.

\section{An Overview of Organizations and Their Programs}

Many public and private organizations participate in conservation easement, land donation, and charitable sale of land programs. Determining who these organizations are and how to contact them often is time consuming and frustrating for private landowners. To facilitate contact between private landowners interested in exploring conservation options for their land and organizations that participate in conservation easement, land donation, and charitable sale of land programs in Florida, we have provided brief descriptions and contact information for these organizations. We have organized this information by national/regional and state/local levels. We also have included a table of local organizations (with contact information) that is organized statewide by county within regions of the state.

\section{National/Regional Level}

\section{Natural Resources Conservation Service}

\section{Florida Contact information:}

State Conservationist: (352) 338-9500

State Resource Conservationist: (352) 338-9543

http://www.nrcs.usda.gov

The Natural Resources Conservation Service (NRCS) is part of the United States Department of Agriculture (USDA). The NRCS puts nearly 70 years of experience to work in assisting owners of America's private land with conserving their soil, water, and other natural resources. Local, state, and federal agencies and policymakers also rely on their expertise. The NRCS works hand in hand with private landowners and federal, state, and nonprofit groups to assist with conservation goals. 


\section{Farm Bill 2002 Easement Programs}

The Farm Security and Rural Investment Act of 2002 was enacted for conservation funding and for focusing on environmental issues. The goal of the "Farm Bill" is to assist farmers and ranchers in meeting environmental challenges on their land and to maintain the long-term quality of our environment and conservation of our natural resources.

In working toward these goals, the NRCS administers multiple programs. The following is a brief overview of those programs that deal with easements.

\section{Farmland Protection Program}

Farmland Protection and Community Planning Staff, NRCS

U.S. Department of Agriculture

P.O. Box 2890

Washington, DC 20013

Phone: (202) 720-9476

Fax: (202) 720-0745

A voluntary program that helps farmers and ranchers keep their land in agriculture. The program provides matching funds to state, tribal, or local governments and non-governmental organizations with existing farmland protection programs to purchase conservation/agricultural easements or other interests in land.

Applicant Eligibility. The following may apply for funds: Any local or state agency, county or groups of counties, municipality, town or township, soil and water conservation district, or Indian tribe or tribal organization that has a farmland protection program that purchases conservation easements for the purpose of protecting topsoil by limiting conversion to non-agricultural uses of land, and that has pending offers.

This program is available in Florida. Individuals must apply through their local agency that handles the purchase of development rights programs.

\section{The Wetlands Reserve Program (WRP)}

Wetlands Reserve Program Coordinator

USDA Natural Resources Conservation Service

P.O. Box 141510

Gainesville, FL 32614-1510

Phone: (352) 338-9500

A voluntary program designed to restore and protect wetlands on private property. Private landowners are eligible for financial incentives to enhance wetlands in exchange for retiring marginal agricultural land.

The USDA NRCS administers the WRP in consultation with the Farm Service Agency (FSA) and other federal agencies. Landowners who wish to participate in the WRP may sell a conservation easement or enter into a cost-share restoration agreement with USDA to restore and protect wetlands on their property. Ultimately, the landowner voluntarily limits future use of the land, yet retains private ownership while working with the NRCS in developing a plan for restoration and maintenance of the wetland. The program offers landowners three options: 1) permanent easements, 2) 30-year easements, and 3) restoration cost-share agreements of a minimum 10-year duration.

\section{Applicant Eligibility:}

Landowner: To offer a conservation easement, you must have owned the land for at least one year prior to enrolling the land in the program, unless 1) the land was inherited, or 2) you can prove that the land was not obtained for the purpose of enrolling it in the program. To participate in a restoration cost-share agreement, you must show evidence of ownership.

Land: To be eligible for the WRP, your land must be restorable and suitable for wildlife benefits. This condition includes: wetlands farmed under natural conditions; farmed wetlands; prior converted cropland; farmed wetland pasture; farmland that has become a wetland as a result of flooding, rangeland, pasture, or timberland, where the hydrology has been significantly degraded and can be restored; riparian areas that are connected to protected wetlands; lands adjacent to protected wetlands that contribute 
significantly to wetland functions and values; and previously restored wetlands. Conservation Reserve Program (CRP) land is eligible if WRP requirements are met.

This program is available in Florida. Individuals must apply through the WRP Coordinator.

\section{United States Fish and Wildlife Service}

http://www.fws.gov/

North Florida

Private Lands Biologist

6620 South Point Drive S.

Suite 310

Jacksonville, FL 32216

Phone: 904-232-2580 (x120)

Fax: 904-232-2404

\section{$\underline{\text { South Florida }}$}

Private Lands Biologist

Florida Panther NWR

3860 Tollgate Blvd.

Suite 300

Naples, FL 34114

Phone: 239-353-8442 (x232)

Fax: $239-353-8640$

\section{Florida Panhandle}

Private Lands Biologist

Panama City Fisheries Office

1601 Balboa Avenue

Panama City, FL 32405

Phone: 850-769-0552

Fax: 850-763-2177

The United States Fish and Wildlife Service (USFWS) is part of the Department of the Interior (DOI). The USFWS mission is to conserve, protect, and enhance fish and wildlife and their habitats for the continuing benefit of the American people.

\section{The USFWS Partners for Fish and Wildlife}

Program provides technical and financial assistance for a wide variety of partners to restore wildlife habitat on private lands. These partners include other federal agencies (such as the NRCS), tribes, state and local governments, conservation organizations, academic institutions, businesses and industries, school groups, and private individuals. Working hand in hand with the NRCS and the Farm Service Agency, USFWS biologists provide habitat-planning guidance and cost-share assistance on projects enrolled in the U.S. Department of Agriculture's Wetland Reserve Program, Wildlife Habitat Incentive Program, Conservation Reserve Program, and other conservation programs.

\section{The Nature Conservancy}

Florida Field Office 222

South Westmonte Drive, Suite 300

Altamonte Springs, FL 32714

Phone: (407) 682-3664, x129

http://nature.org

http://nature.org/wherewework/northamerica/states/ florida/

http://nature.org/joinanddonate/giftandlegacy/

The Nature Conservancy (TNC) is a private, non-profit organization dedicated to preserving the plants, animals, and natural communities that represent the diversity of life on Earth by protecting the lands and waters they need to survive. TNC works collaboratively with public and private organizations to achieve conservation goals. TNC also has its own programs. The Immediate Land Donation Program welcomes gifts of real property including vacation homes, farms, and commercial buildings. They call these gifts "Trade Lands" because after a landowner donates their property, TNC sells it and uses the proceeds to help fund efforts to protect and preserve natural areas. These gifts can provide landowners with significant tax and financial advantages. The Charitable Remainder Unitrust Program enables private landowners to realize lifetime or term income, immediate tax savings, and the ability to leave a legacy.

\section{Sustainable Forests Alliance}

http://www.southernsustainableforests.org/

The Sustainable Forests Alliance (SFA) is a coalition of nonprofit conservation organizations, forestry practitioners, and others working to provide private landowners information, forestry expertise, 
and legal assistance so that they can protect their forests for generations to come while realizing sustainable income.

The Sustainable Forests Alliance put together the following list of private organizations that work in the southeastern United States and that deal in conservation easements, land donations, and purchasing land.

\section{The Conservation Fund}

http://www.conservationfund.org/

The Conservation Fund

1800 N Kent Street, Suite 1120

Arlington, Virginia 22209-2156

Phone: 703-525-6300

Fax: 703-525-4610

The Conservation Fund forges partnerships to protect America's legacy of land and water resources. Through land acquisition, community initiatives, and leadership training, the fund and its partners demonstrate sustainable conservation solutions emphasizing the integration of economic and environmental goals.

\section{Land Trust Alliance}

1331 H Street NW, Suite 400

Washington, DC 20005

Phone 202-638-4725

Fax: 202-638-4730

http://www.lta.org/

The Land Trust Alliance promotes voluntary land conservation and strengthens the land trust movement by providing the leadership, information, skills, and resources land trusts need to conserve land for the benefit of communities and natural systems.

\section{Trust for Public Land}

116 New Montgomery Street, 4th Floor

San Francisco, CA 94105

Phone: 415-495-4014

Fax: 415-495-4103

Founded in 1972, the Trust for Public Land (TPL) is the only national nonprofit working exclusively to protect land for human enjoyment and well-being. TPL helps conserve land for recreation and spiritual nourishment and to improve the health and quality of life of American communities.

\section{Wildlife Land Trust}

2100 L Street, NW
Washington, DC 20037
Phone: 1-800-729-SAVE

The Wildlife Land Trust works with landowners worldwide to protect wild animals by permanently preserving their natural habitats. Lands protected by the trust provide wild animals with a safe and nurturing environment, free from harmful human interference. Recreational and commercial hunting and trapping are strictly prohibited on trust-protected sanctuaries.

\section{Stewardship America}

Stewardship America, Inc.

621 NW 53rd Street, Suite 240

Boca Raton, Florida 33487

Phone: 561-995-1474

Fax: 561-995-1499

http://privatelands.org/

Stewardship America is working to advance initiatives that maintain thriving rural economies that include robust agricultural economies and healthy natural environments.

Initiated in 1993 in southwest Florida, Stewardship America evolved into a national program through an open, consensus-building process involving more than 1,000 participants. Stewardship America was designed to address virtually every conservation need and opportunity on private agricultural and forestry lands in the United States, has been incorporated into state law in Florida and Oregon, and was approved by the U.S. Congress as part of the 2002 Farm Bill.

\section{The Farmland Stewardship Program}

The Farmland Stewardship Program (formerly known as the "Panthers \& Private Lands" project and as a "Resource Conservation Agreement") uses a service contract to combine or coordinate two or more different conservation or regulatory programs into a single agreement with a single application. The agreement customizes these programs to the specific 
needs, opportunities, and challenges offered by individual parcels of land and overcomes administrative obstacles that previously may have limited the use of these programs on eligible agricultural lands. The Farmland Stewardship Program can also be used as a stand-alone program to provide incentive payments to producers to implement conservation practices on private lands, or it can be used to complement and work together with any other program or programs, including local and private programs. When existing programs do not address a particular need on a specific property, the Farmland Stewardship Program can be used to fill in the gaps. The program provides payments to private landowners and operators of agricultural and forestry enterprises for implementing conservation practices that enhance environmental goals.

Two web sites have been in operation since 1997 that explain the program in detail (http://privatelands.org) and describe the workshops that led to the development of the concept (http://fl-panther.com).

The Farmland Stewardship Program can be implemented through "stewardship agreements," as provided in legislation passed in the states of Florida and Oregon in 2001 and through Sec. 2003 of the 2002 Farm Bill.

\section{Contact Information:}

Stewardship America, Inc.

621NW 53rd Street, Suite 240

Boca Raton, Florida 33487

Phone: 561-995-1474; Fax: 561-995-1499

http://privatelands.org

\section{State Level}

In addition to conservation options provided by agencies and organizations that operate at the national and regional levels, a few programs are specific to Florida.

\section{The Florida Forever Program}

Division of State Lands

Office of Environmental Services

3900 Commonwealth Blvd.
Mail Station \#140

Tallahassee, FL 32399-3000

Phone: 850-245-2784

The Florida Forever program is a state land acquisition and conservation program. It replaces the Preservation 2000 Program (P-2000), which placed more than 1.25 million acres of Florida natural areas into public ownership. The Florida Forever Program encompasses a wider range of goals, including restoration of damaged environmental systems, water resource development and supply, increased public access, public lands management and maintenance, and increased protection of land by acquisition of conservation easements. As such, the Florida Forever Program serves as funding for a mosaic of land and water conservation programs. Public agencies and private organizations work together to meet specific objectives for each individual project under the Florida Forever Program.

Federal, state, and local government agencies, conservation organizations, and private citizens may propose areas for conservation under the Florida Forever Program. Sponsors are required to inform landowners that their property has been nominated for state acquisition (note: Florida Forever is almost exclusively a volunteer program). The Acquisition and Restoration Council consists of representatives from state agencies and persons appointed by the Governor. Approved projects are submitted to the Governor and Cabinet. The Division of State Lands negotiates with owners of endorsed projects on behalf of the people of Florida. The negotiated purchase price is submitted to the Governor and Cabinet. Approval of the Governor and Cabinet is required for the purchase of lands under the Florida Forever Program.

\section{Florida Division of Forestry}

http://www.fl-dof.com

The Florida Division of Forestry (DOF), which is a division of the Florida Department of Agriculture and Consumer Services (FDACS), administers the Rural and Family Lands Protection Act.

The Rural and Family Lands Protection Act is primarily designed to conserve agricultural lands. The Act is designed to implement a program to meet 3 
specific needs: 1) protect valuable agricultural lands; 2) create easement documents that ensure sustainable agricultural practices and reasonable protection of the environment without jeopardizing continued economic viability of agricultural operations; and 3) protect natural resources, not as its primary purpose, but in conjunction with economically viable agricultural operations.

Rural and Family Lands Protection

FL Dept. of Agriculture and Consumer

Services, Division of Forestry

3125 Connor Blvd.

Mail Station C-25

Tallahassee, FL 32399-1650

http://www.fl-dof.com/Pubs/

RandF_landprotection_act.pdf

\section{The Nature Conservency}

The Nature Conservancy

222 S. Westmonte Drive

Suite 300

Altamonte Springs, FL 32714

Phone: (407) 682-3664

Fax: (407) 682-3077

http://nature.org/wherewework/northamerica/ states/florida/press/press693.html

The Nature Conservancy (TNC) also is working with the USDAs Natural Resource Conservation Service to administer the Florida Lands and Outstanding Waters (FLOW) program. FLOW is a wetland restoration program for private ranches in the Kissimmee-Okeechobee Basin. FLOW provides economic incentives to ranchers to protect and restore hydrologic function, maintain agricultural productivity, and keep the land in private ownership. Invasive plant control is an important component of FLOW and a key strategy is establishing conservation and flowage easements over targeted areas. These easements include sections related to management of invasive species that can provide guidance for easements in other conservation areas.

\section{Conservation Trust for Florida}

Conservation Trust for Florida Micanopy, FL 32667-0134
Phone: (352) 466-4581

Fax: (352) 466-7014

http://www.conserveflorida.org/

E-mail: info@conserveflorida.org

The Conservation Trust for Florida (CTF) protects rural lands vital to the state's character and economy through conservation easements, land purchases, and by helping rural landowners retain their traditional and productive land-use activities.

CTF was created as a nonprofit 501(c)3 land trust to protect dwindling landscapes. Its hope is that rural lifestyles may continue, open lands may be protected for future generations, and urban development may be more effectively directed away from culturally, aesthetically, historically, and ecologically valuable rural areas. Its focus is working with rural landscapes - family farms, ranches, and timberlands - as well as natural areas. CTF especially is concerned with restoring or retaining landscape connections.

\section{Local Level (includes listings by region of the state and by county)}

In addition to conservation options provided by the agencies and organizations previously described, a number of programs are available that are specific to regions or counties within Florida. We have adopted the five regions created by the Water Management District (WMD) within the state of Florida to assist private landowners in contacting organizations working within their areas (Figure 1).

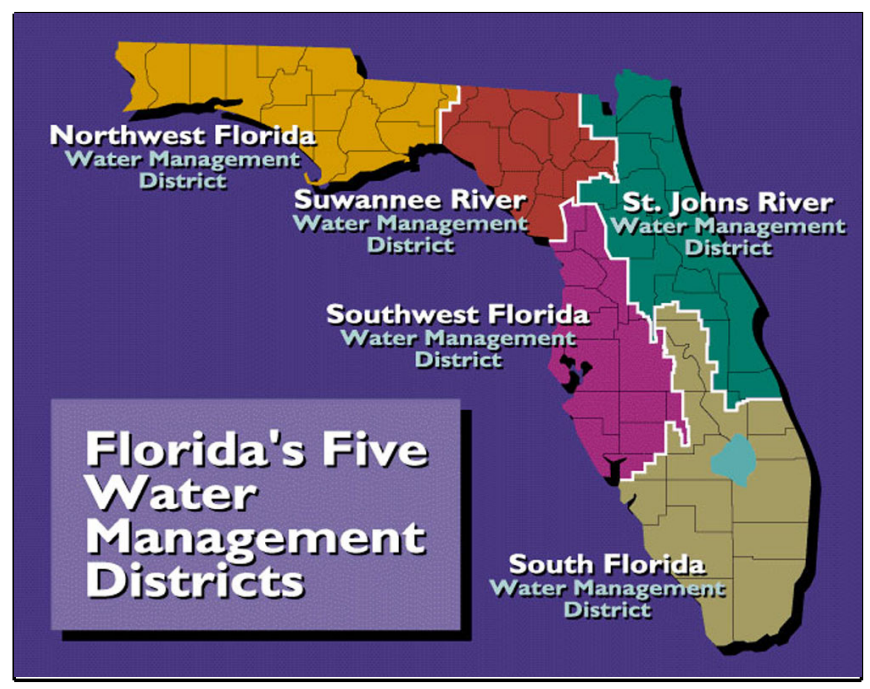

Figure 1. Figure 1. Regions and counties within Florida (courtesy of Saint Johns River Water Management District). 
For each region, we've provided two tables. Agencies and organizations that operate in more than one county may be found in the first table for each region. The second table lists programs specific to counties within regions. Note that some organizations may be listed in more than one region or county. The conservation options offered by each organization are designated as CE (conservation easements), LD (land donations), and CS (charitable sale of land).

Counties that lacked conservation programs were not included in tables listing options by county. Note: information current as of April 2003.

For Additional Information

Catalog of Federal Domestic Assistance: http://www.cfda.gov

Conservation Collier:

www.voteconservation2002.org

Conservation Trust for Florida:

http://www.conserveflorida.org/

Florida Department of Agriculture and Consumer Services: http://doacs.state.fl.us/

Florida Department of Agriculture and Consumer Services, Division of Forestry. Bronson, Charles H. Agriculture and Resource Conservation Assessment, A requirement of the Rural and Family Lands Protection Act. December 19, 2001. http://www.fl-dof.com/Pubs/ RandF_landprotection_act.pdf

Florida Department of Environmental Protection: http://www.dep.state.fl.us

Florida Stewardship Foundation: http://fl-stewardship.com

Harrison, G.A. and Richardson, J.J. Conservation Easements in Indiana.

http://www.agcom.purdue.edu/AgCom/Pubs/ID/ID231/ID-231.html

Land Trust Alliance: http://www.lta.org

Massachusetts Land Trust Coalition: http://www.massland.org
National Resource Conservation Service: http://www.nrcs.usda.gov

Private Lands: http://privatelands.org

Reynolds, John E. Urbanization and Land Use Change in Florida and the South. Southern Rural Development Center, Proceedings of a Regional Workshop, SERA-IEG-30, June 2001. http://srdc.msstate.edu/publications/220_ch2.pdf

Stewardship America:

http://www.stewardshipamerica.com/

Sustainable Forests Alliance:

http://www.southernsustainableforests.org/

The Nature Conservancy: http://nature.org/

United States Fish and Wildlife Service: http://www.fws.gov/

University of Florida, School of Forest Resources and Conservation:http://www.sfrc.ufl.edu/Extension 


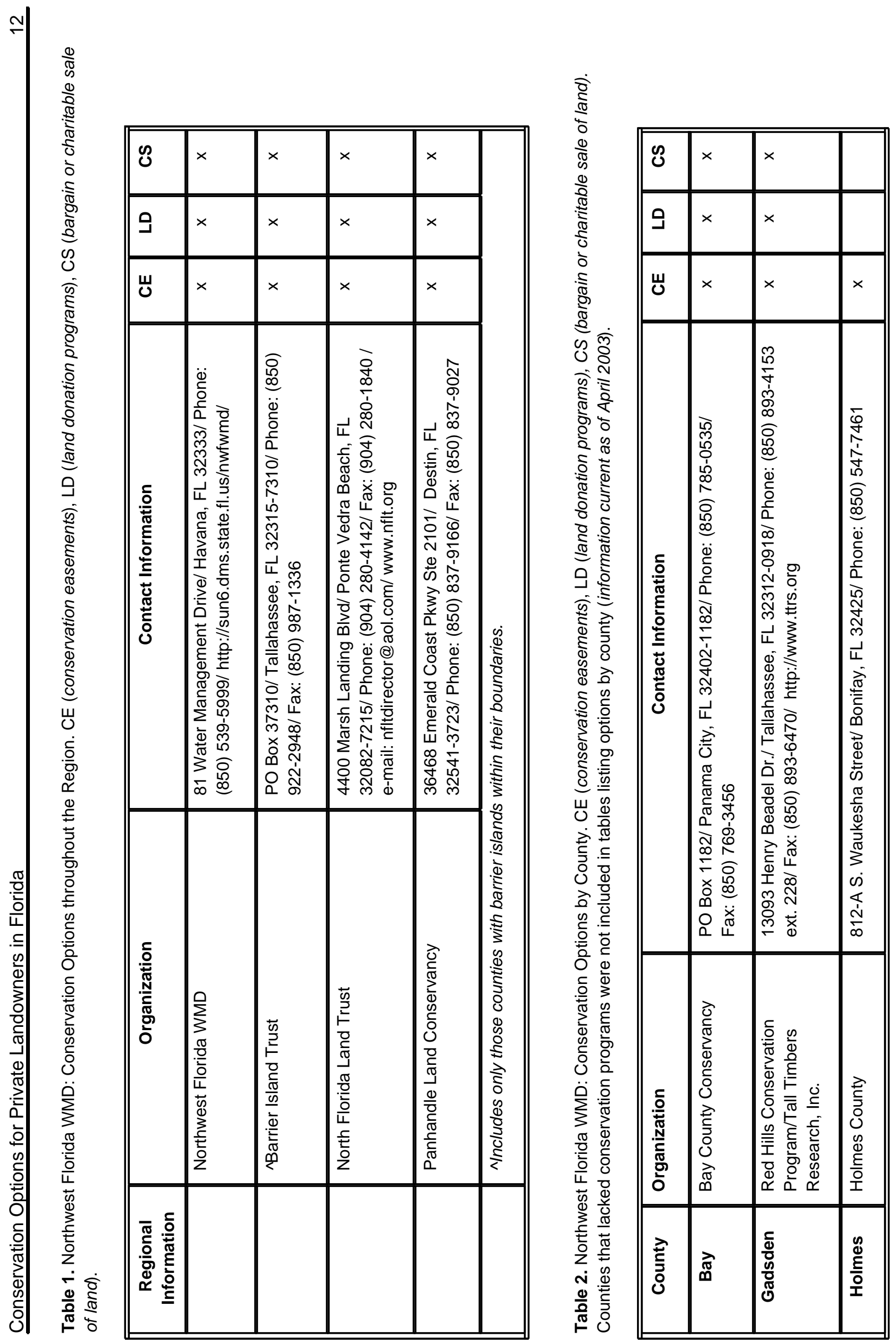




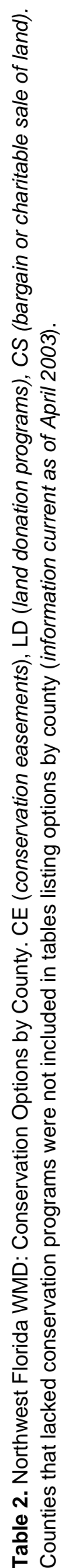

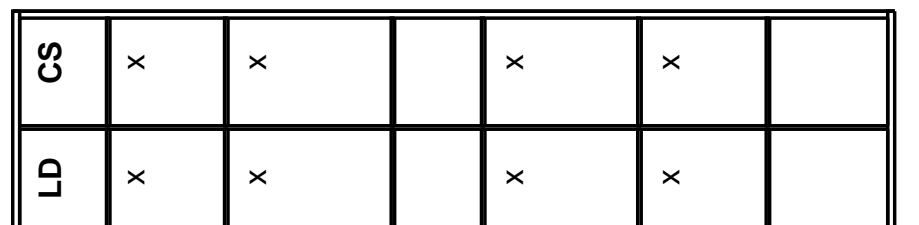

$\stackrel{2}{\circ}$
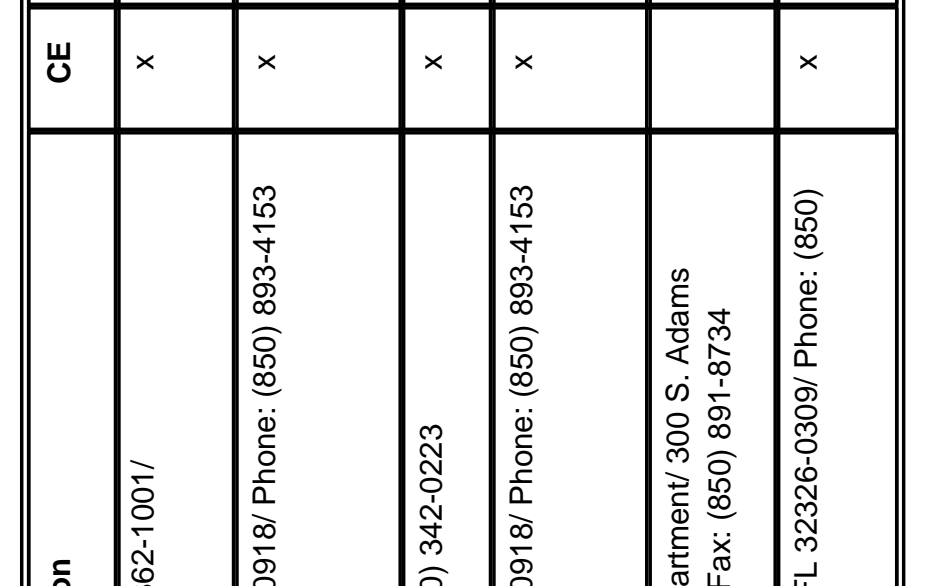

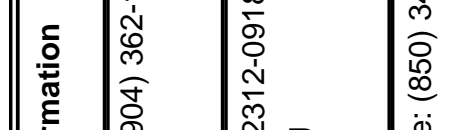

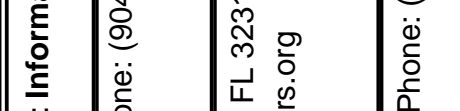

ํㅗㄴ

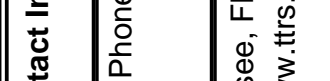

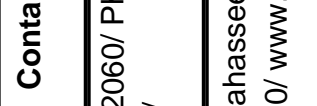

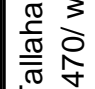

एक

每

중

ㄴ

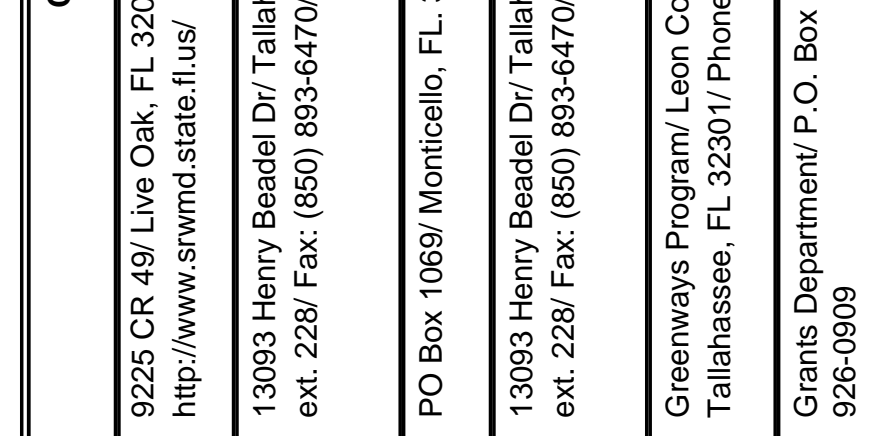

ले

○

$\frac{0}{2}$

है

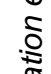

ญ

ठํ.

U

흠

অ

$\stackrel{0}{=}$

폭

을

동

응

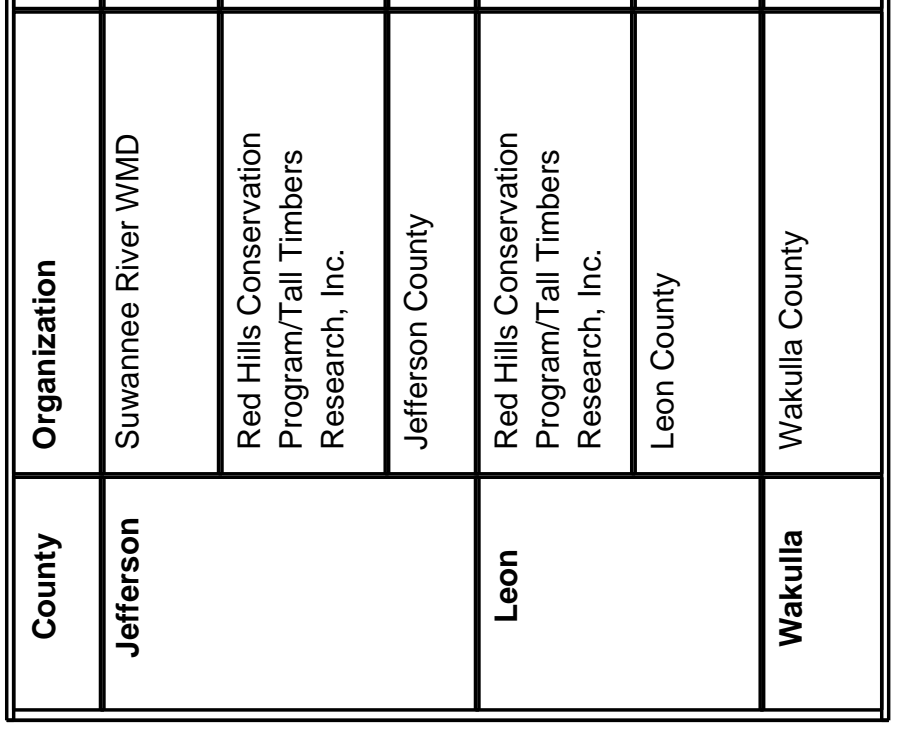

음

อ

¿ั

$\sum_{j}$

ऐ

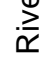

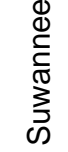

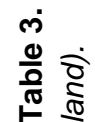

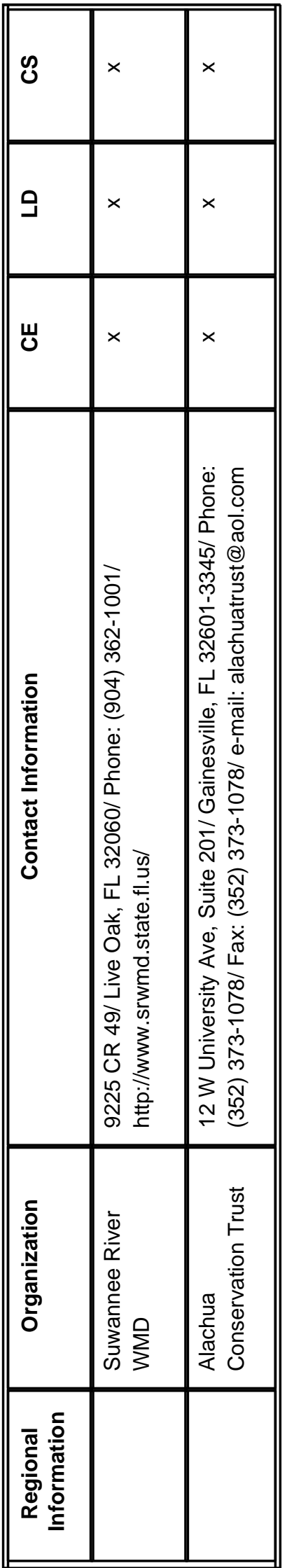




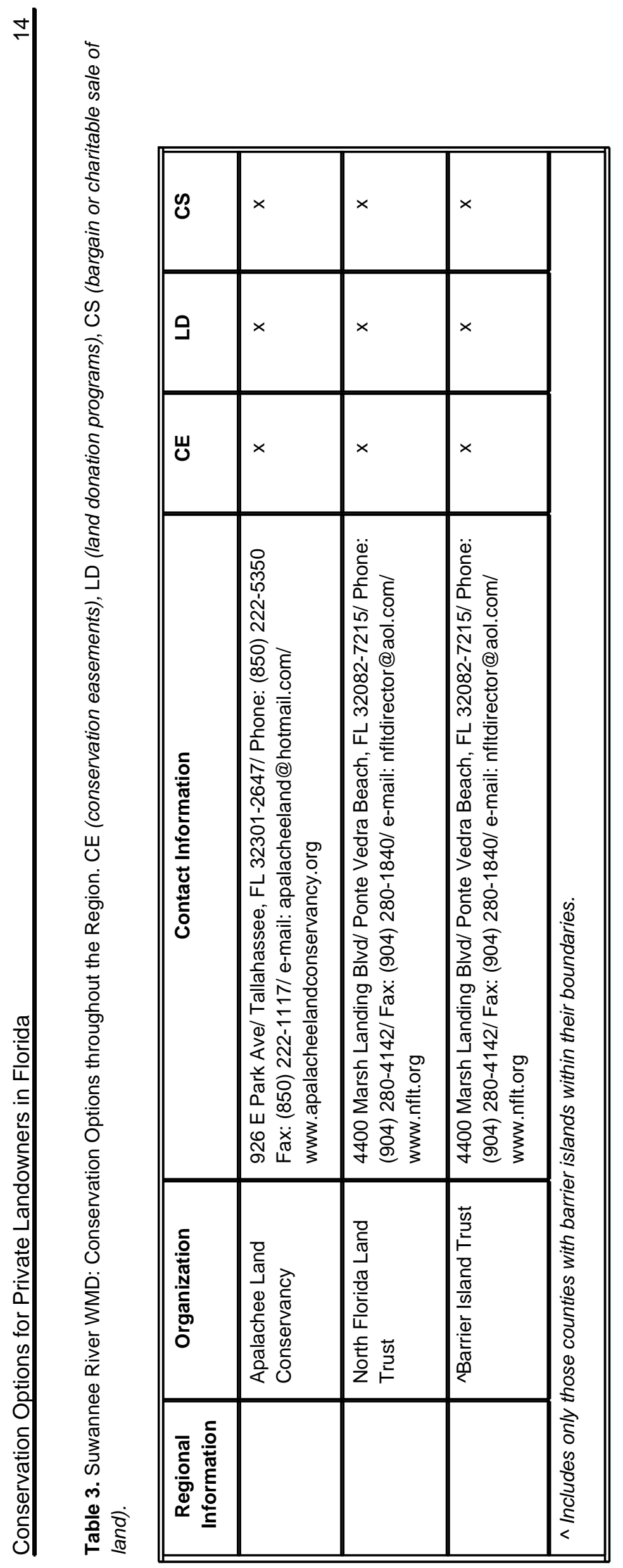

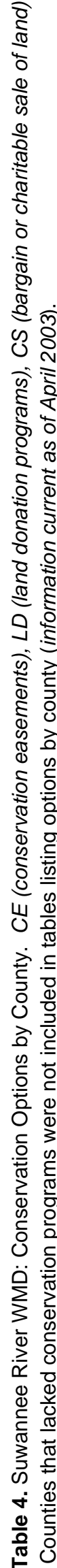

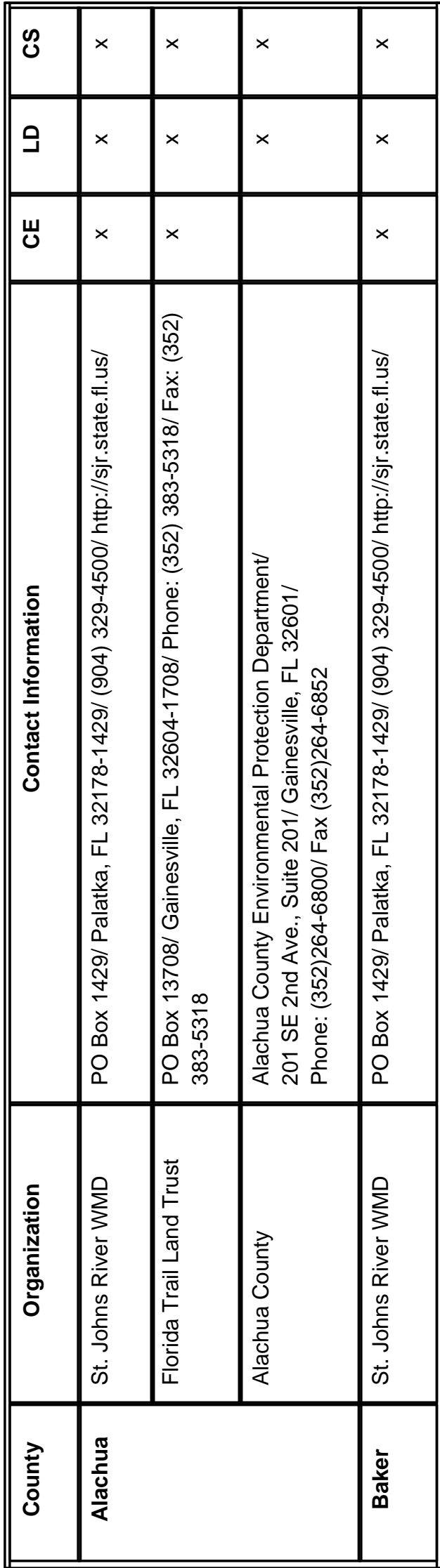




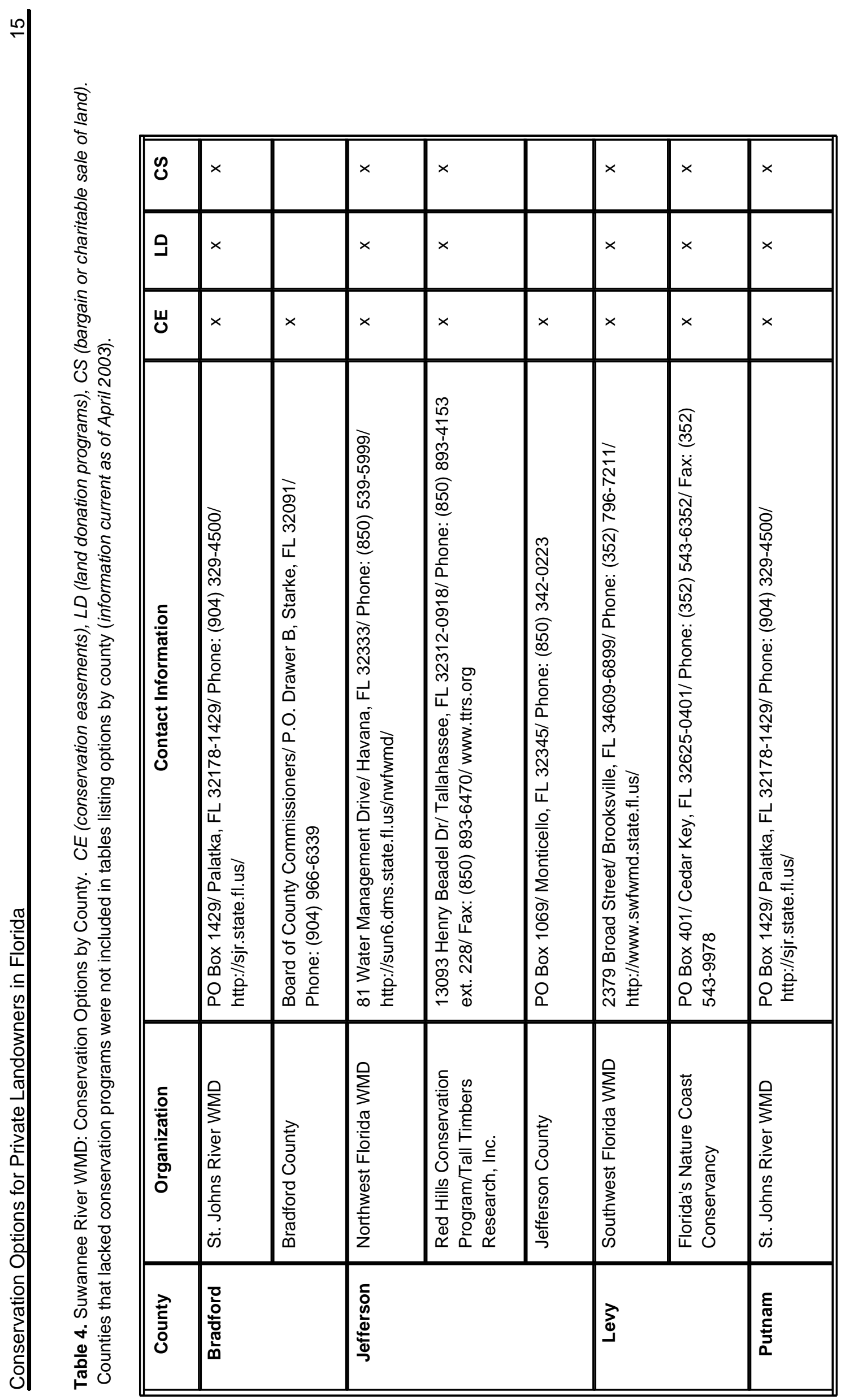




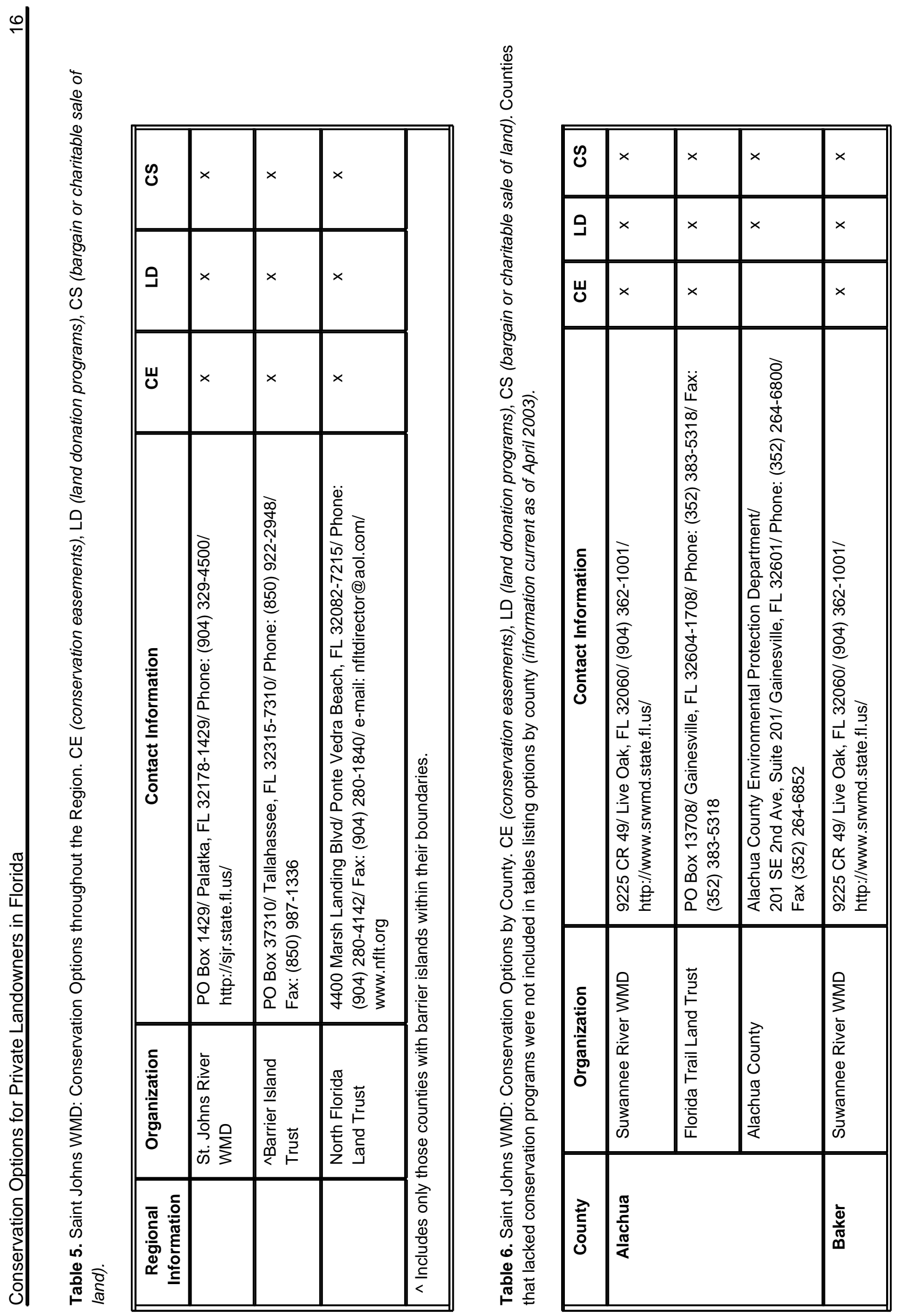




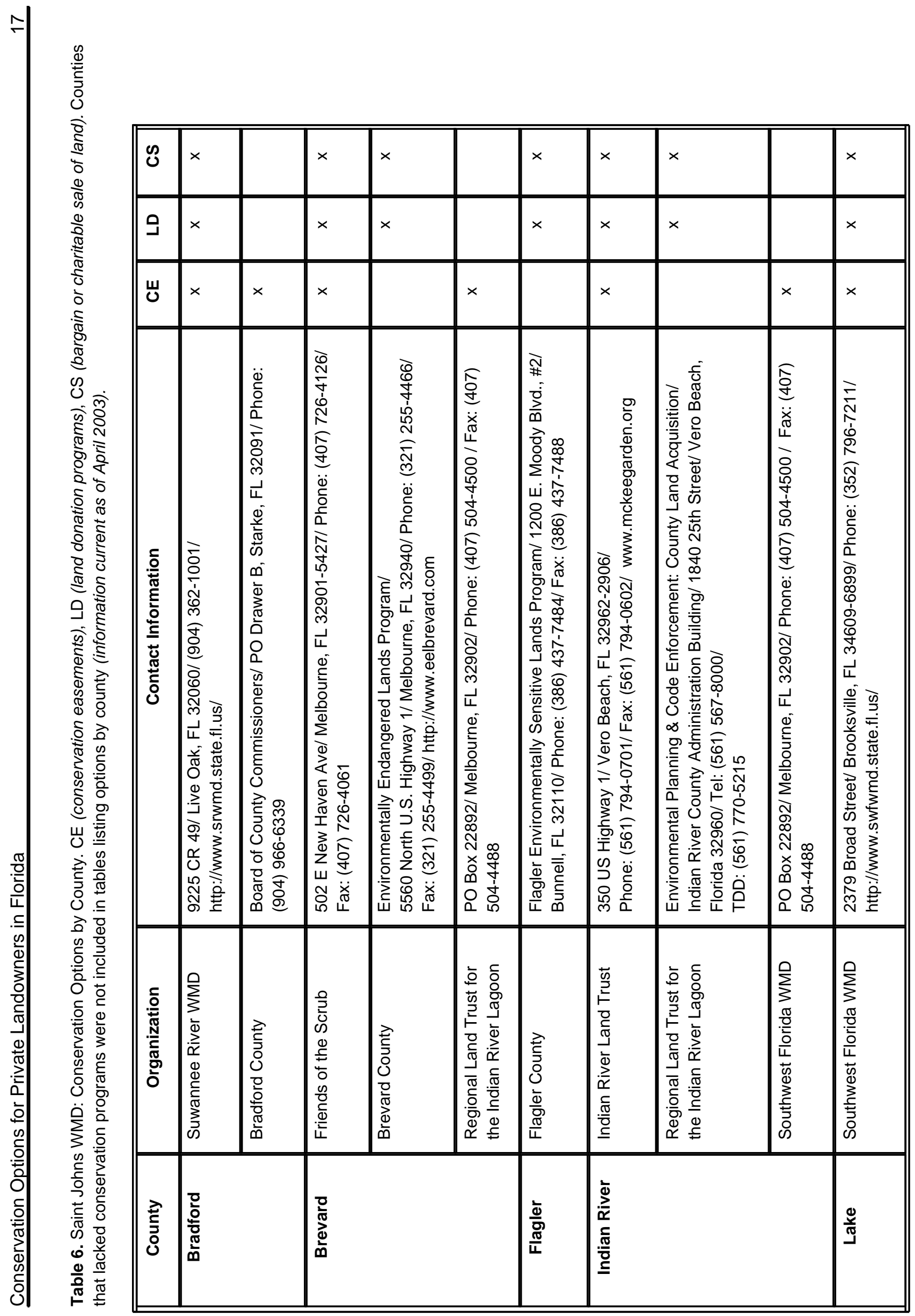




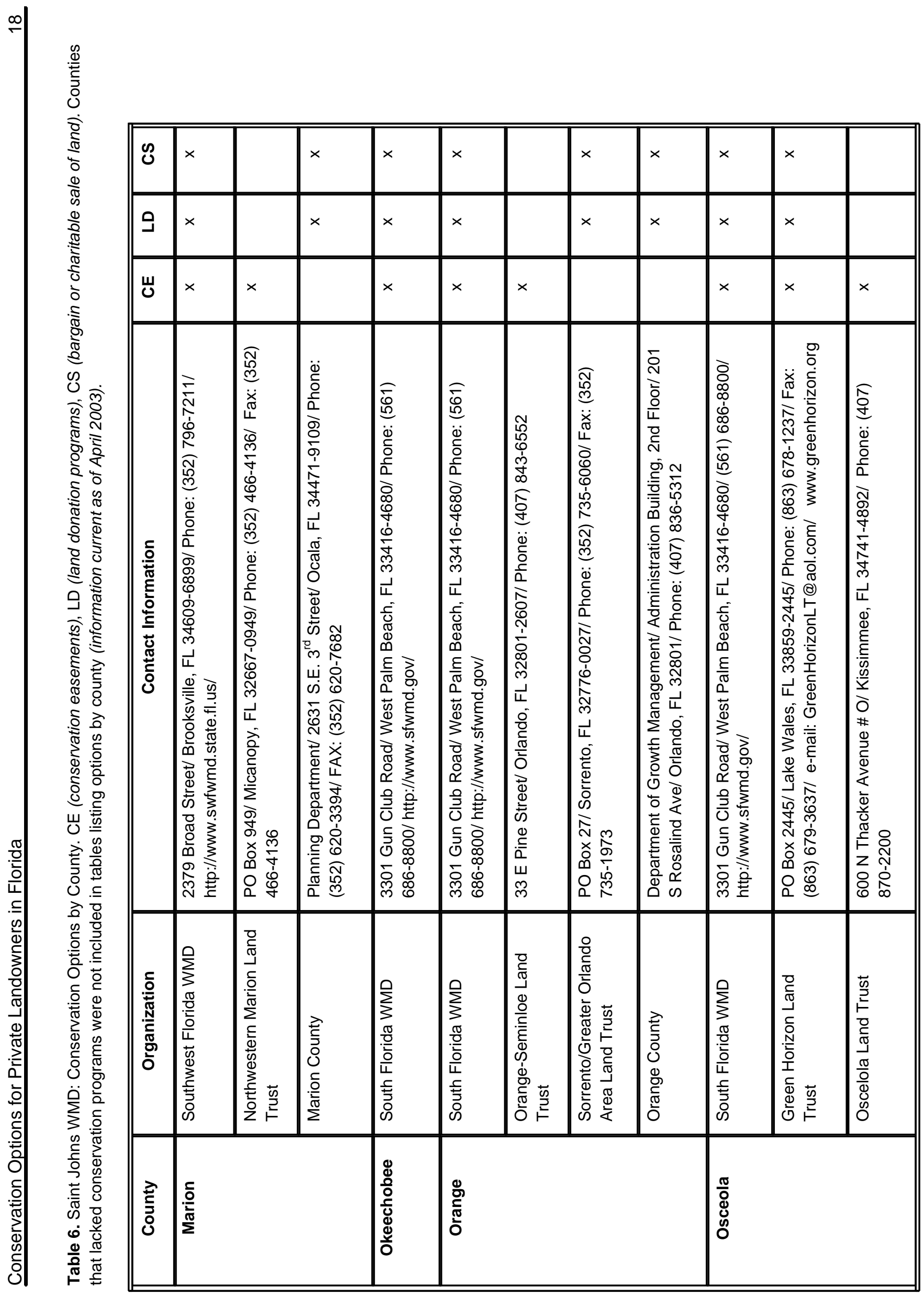




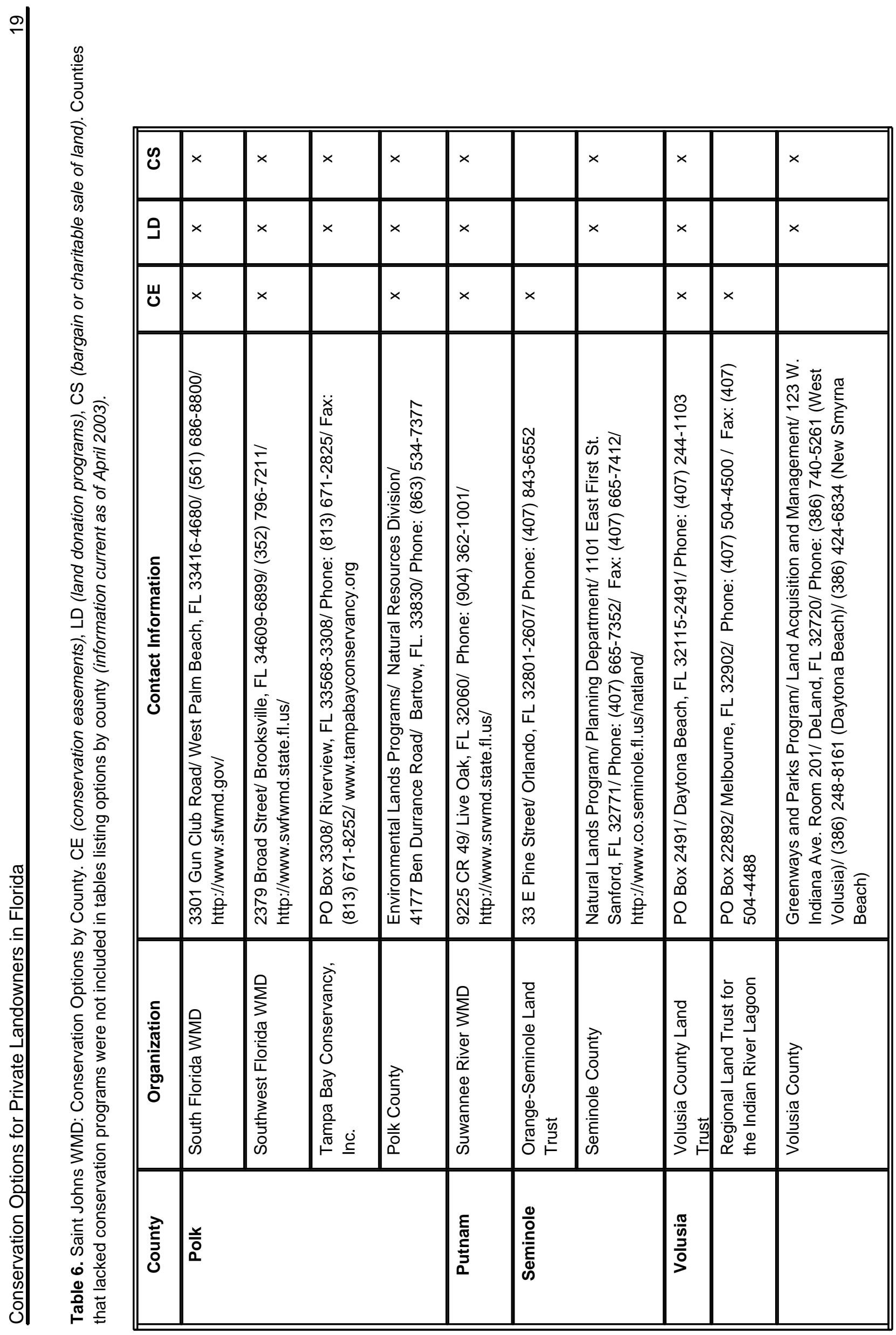




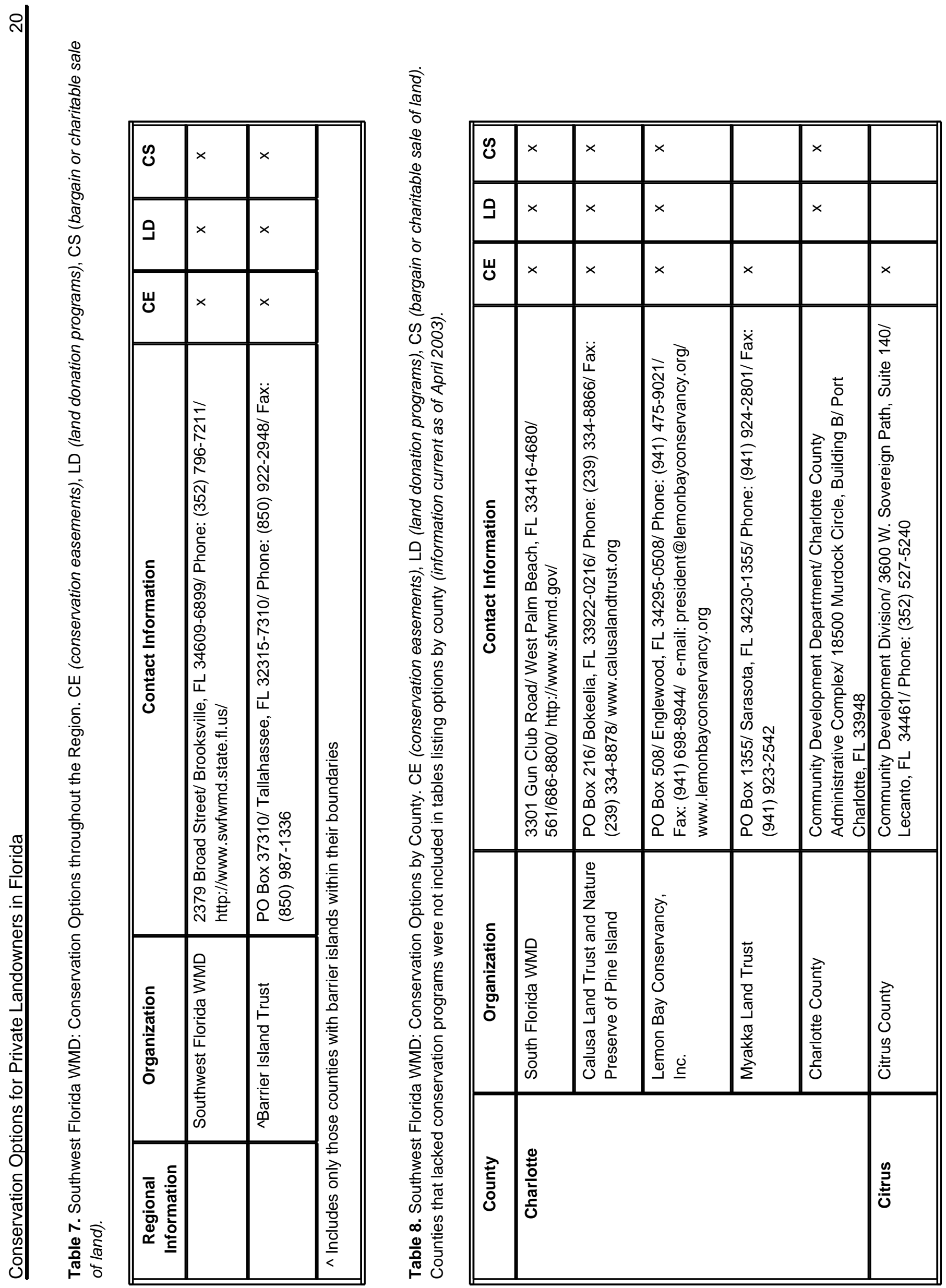




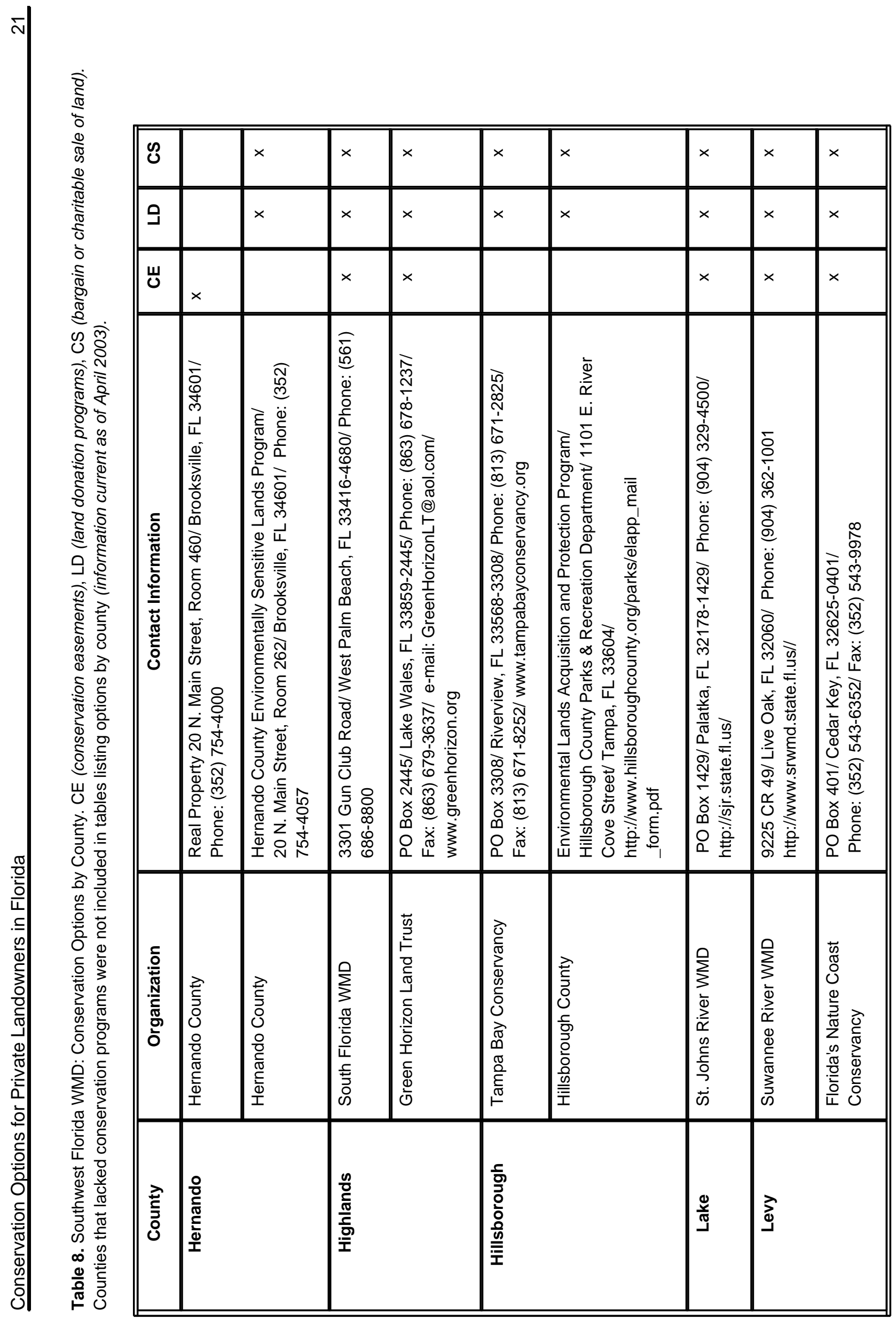




\begin{tabular}{|c|c|c|c|c|c|c|c|c|c|c|c|}
\hline ஜு & $\times$ & & $x$ & $x$ & & $\times$ & $x$ & $x$ & $x$ & $\times$ & $x$ \\
\hline 9 & $x$ & & $x$ & $\times$ & & $\times$ & $x$ & $x$ & $\times$ & $\times$ & $\times$ \\
\hline Ј & $\times$ & $\times$ & & $\times$ & $\times$ & & & $x$ & & & \\
\hline 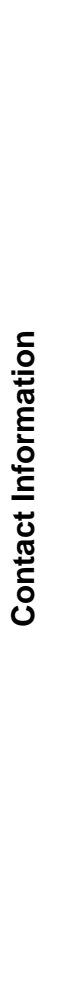 & 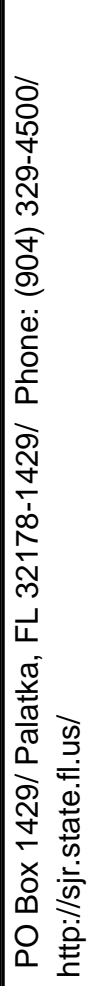 & 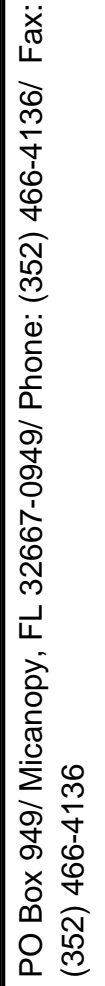 & 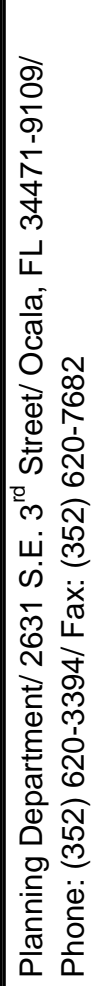 & 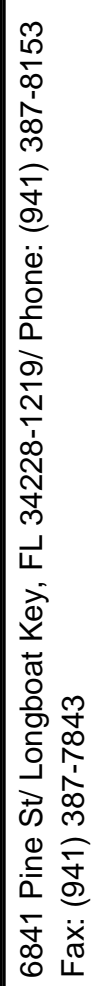 & 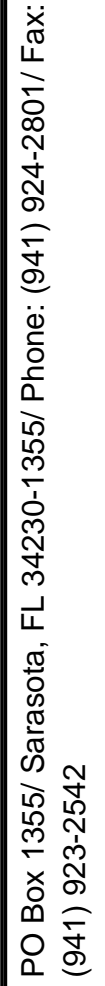 & 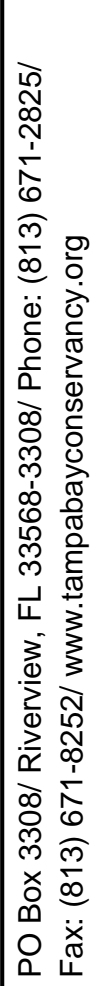 & 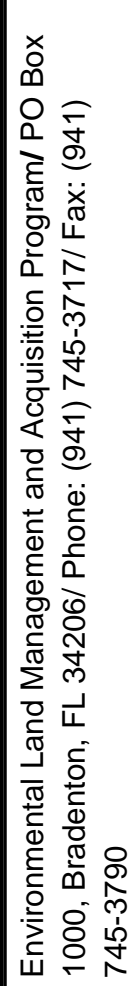 & 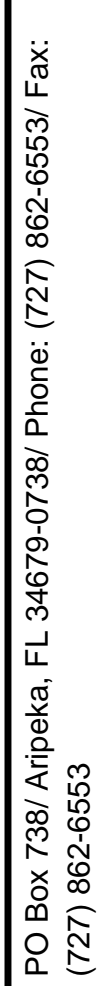 & 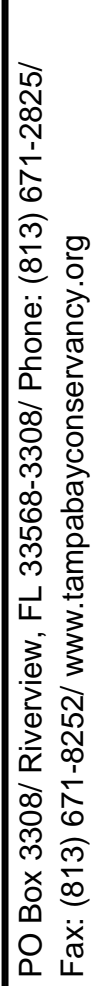 & 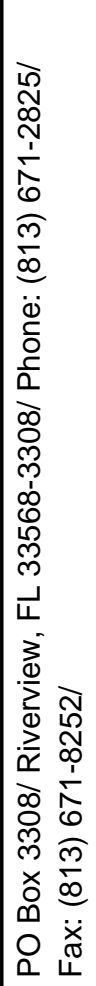 & 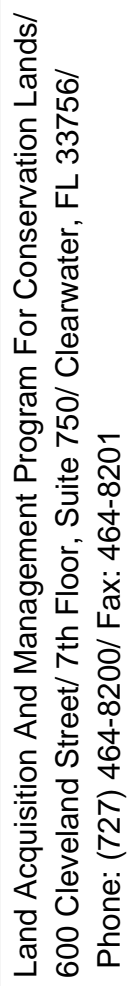 \\
\hline 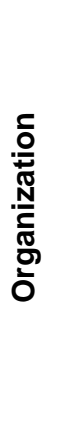 & 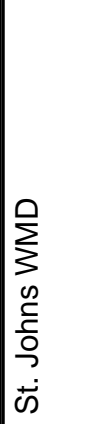 & 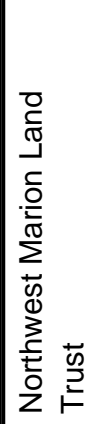 & 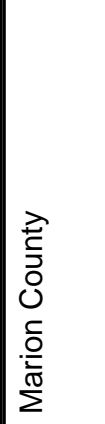 & 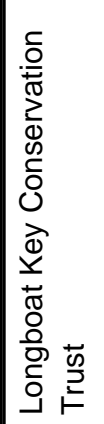 & 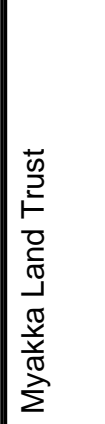 & 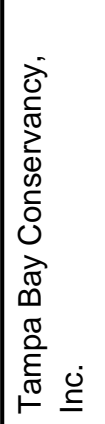 & 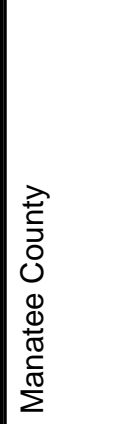 & 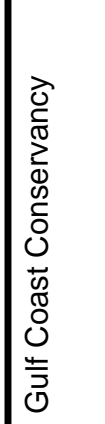 & 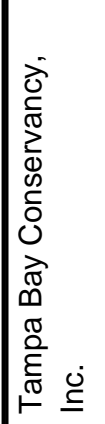 & 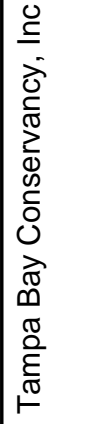 & 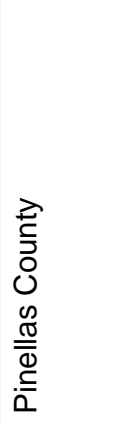 \\
\hline 空 & 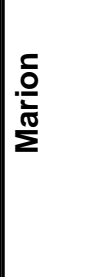 & & & 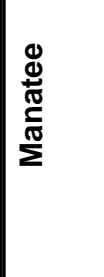 & & & & 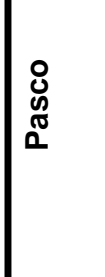 & & 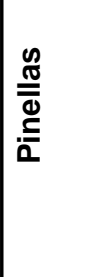 & \\
\hline
\end{tabular}




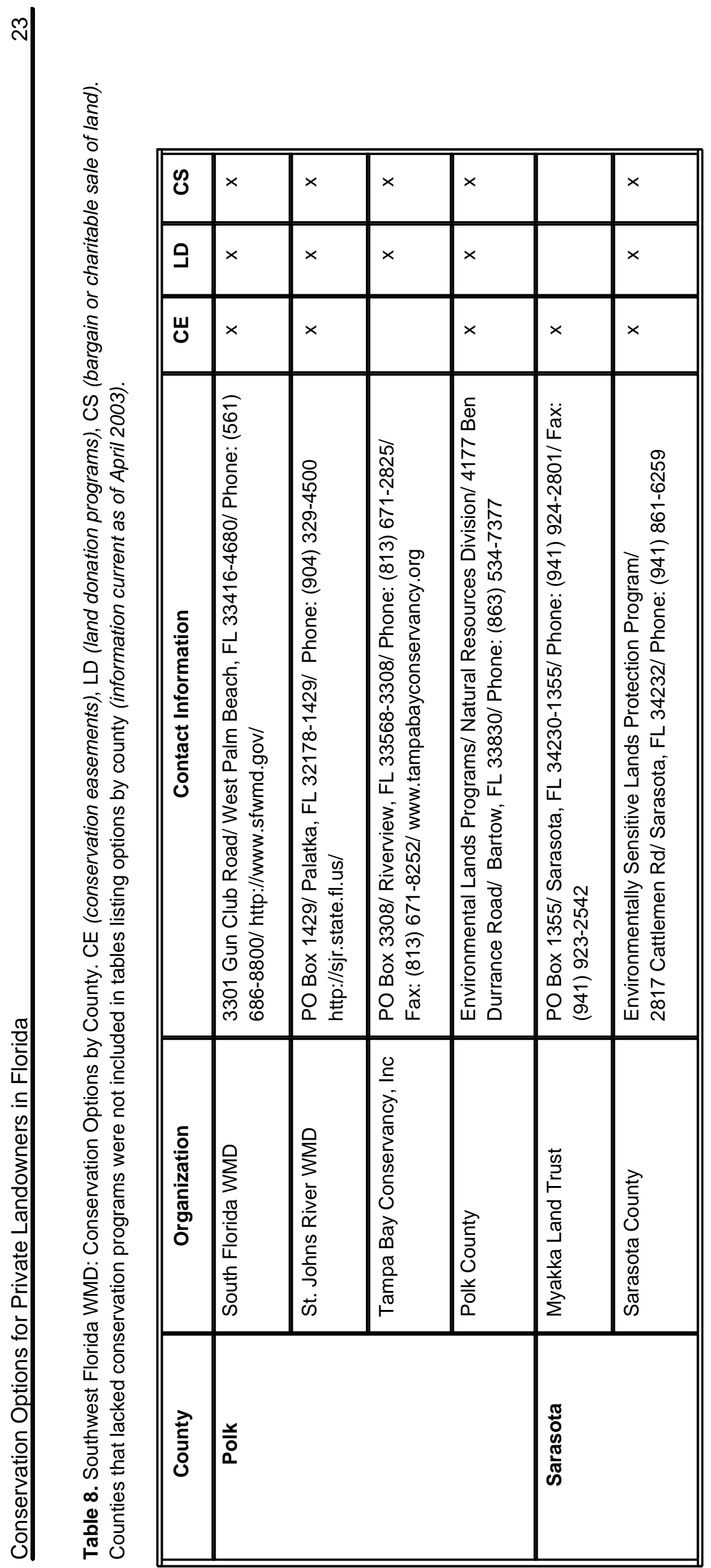

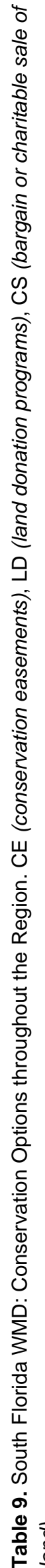

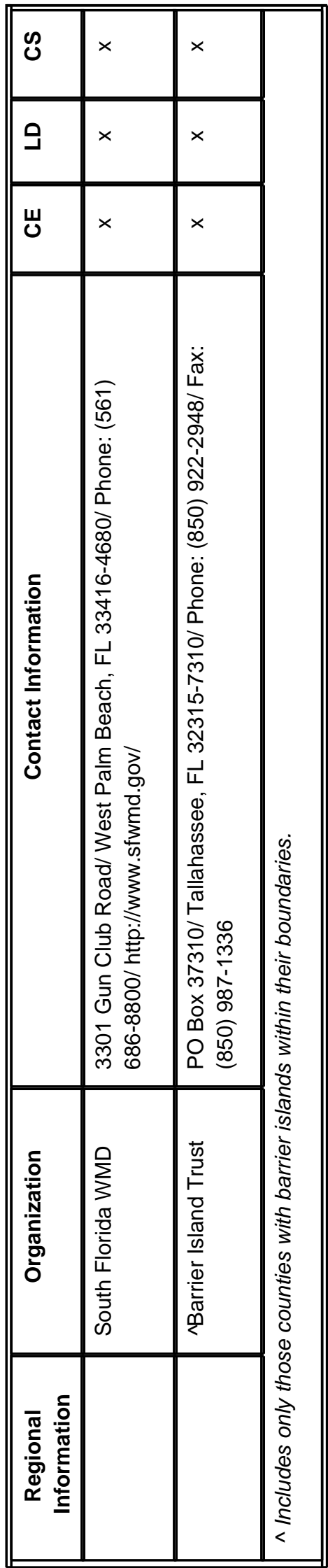




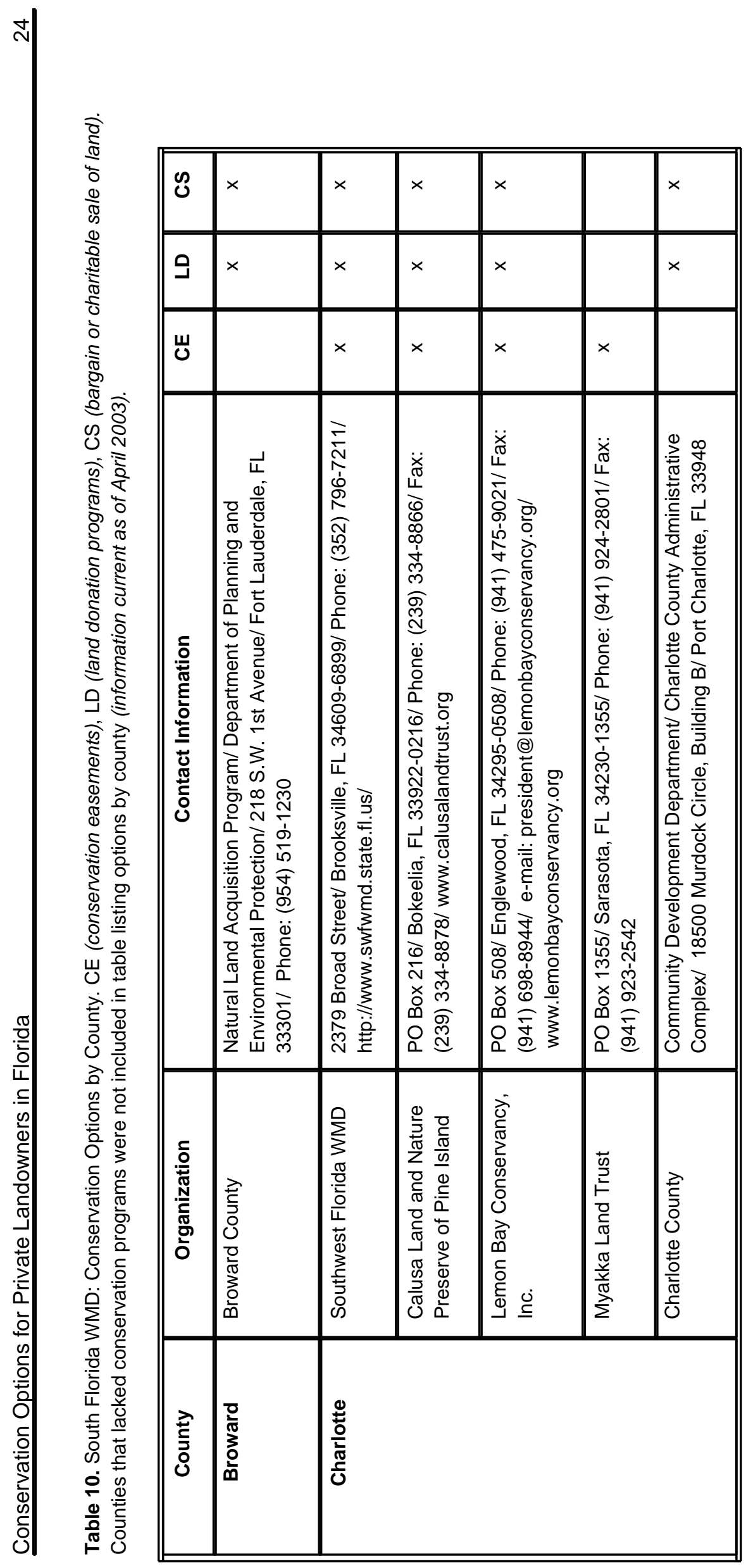




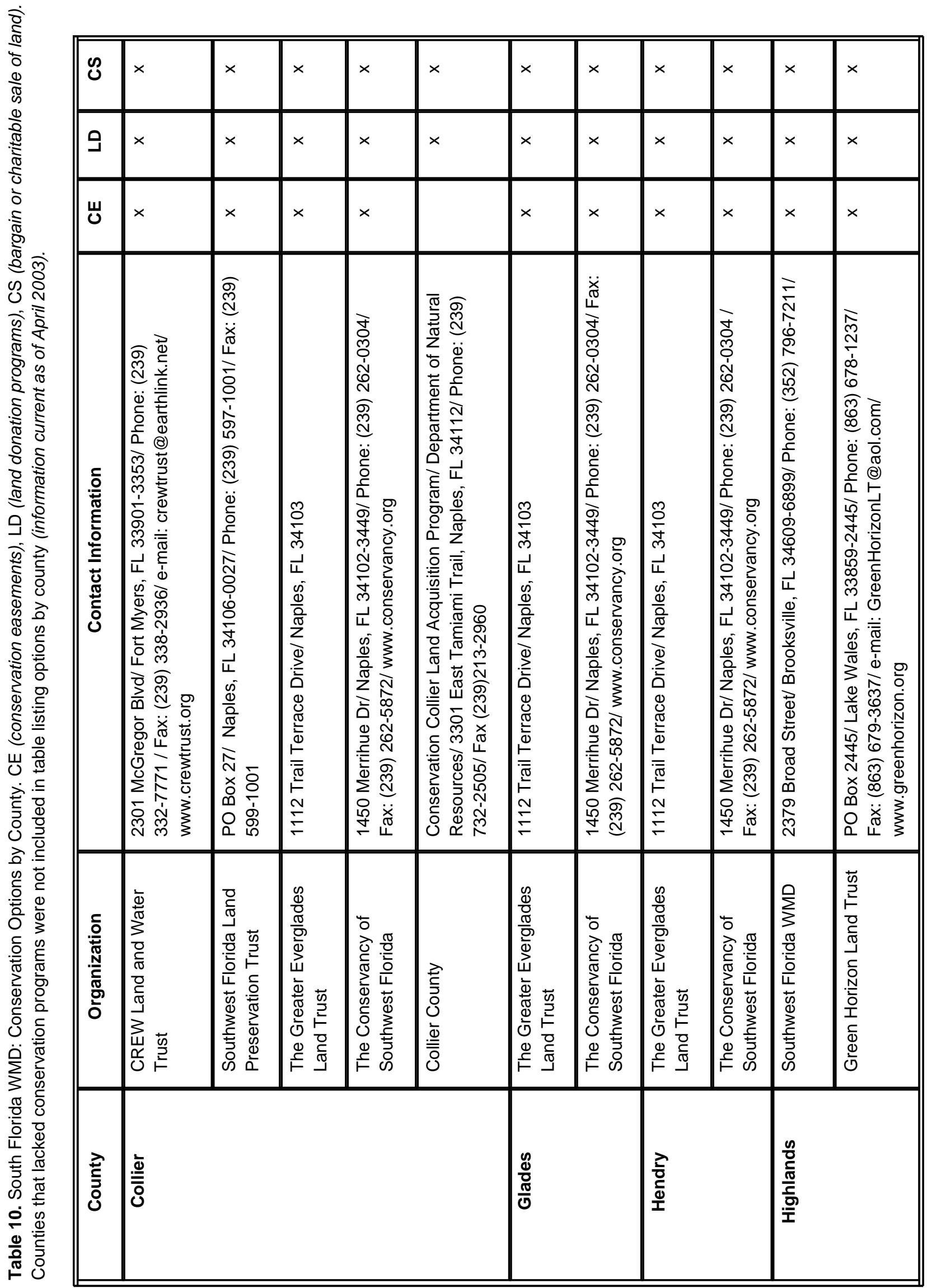




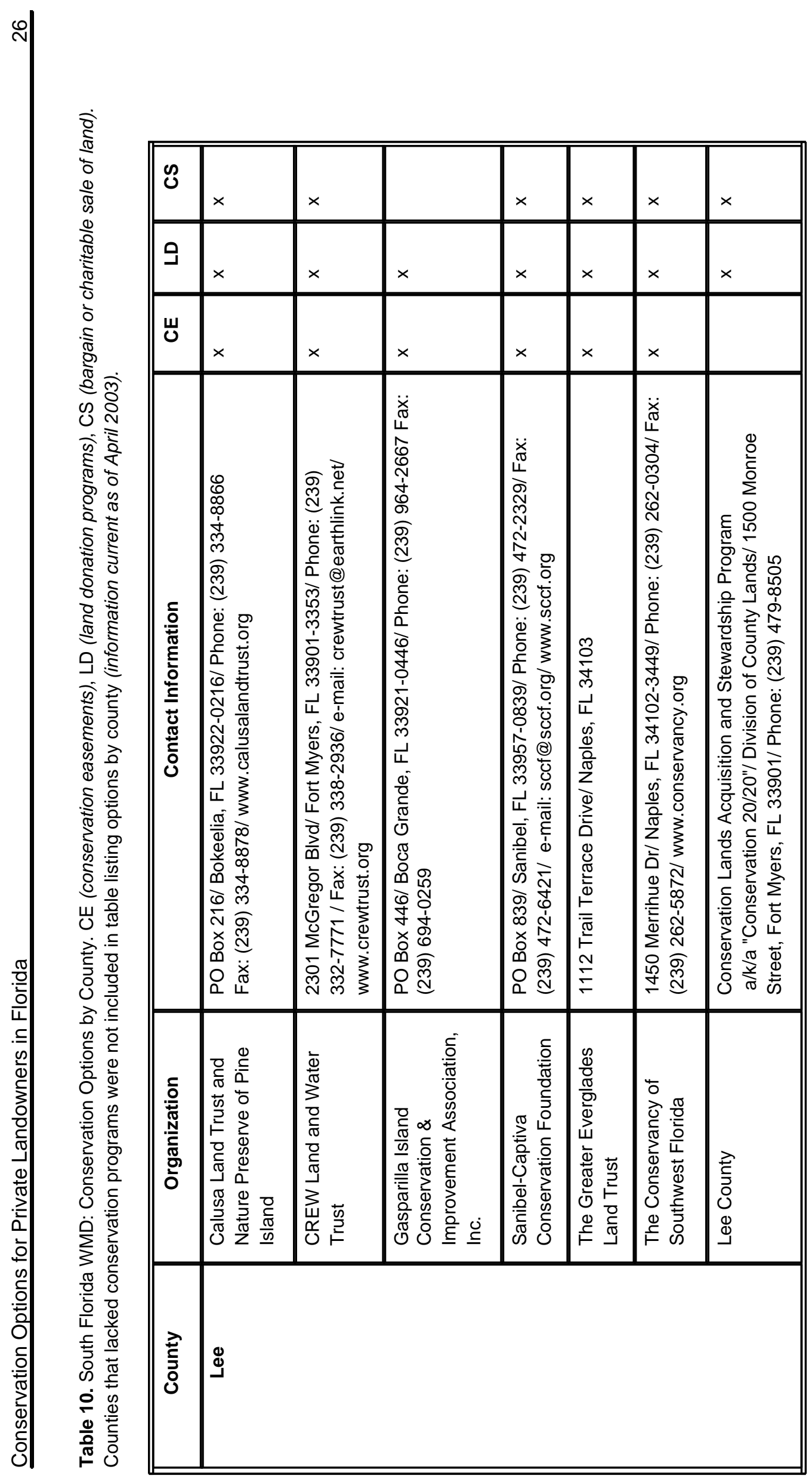




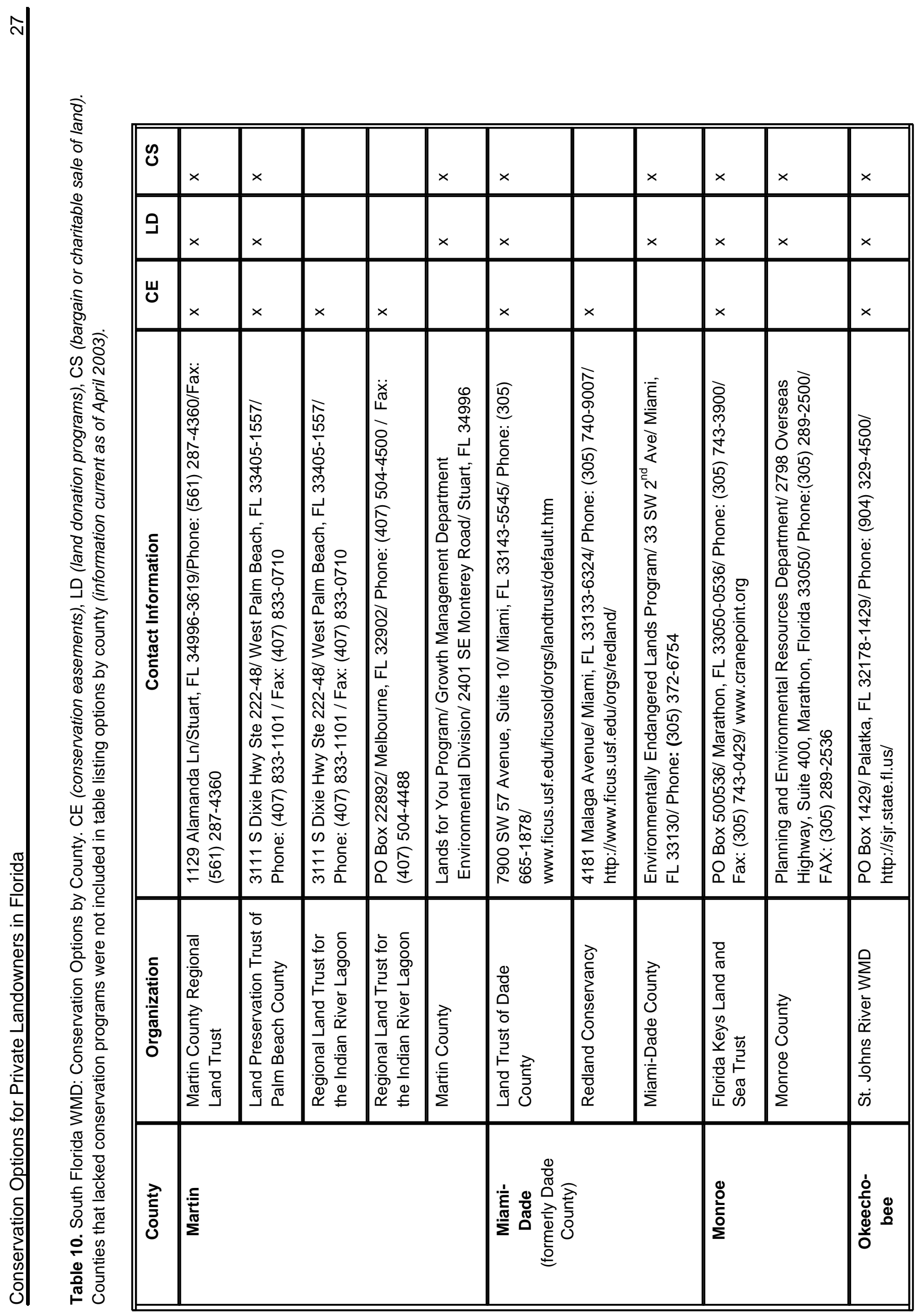




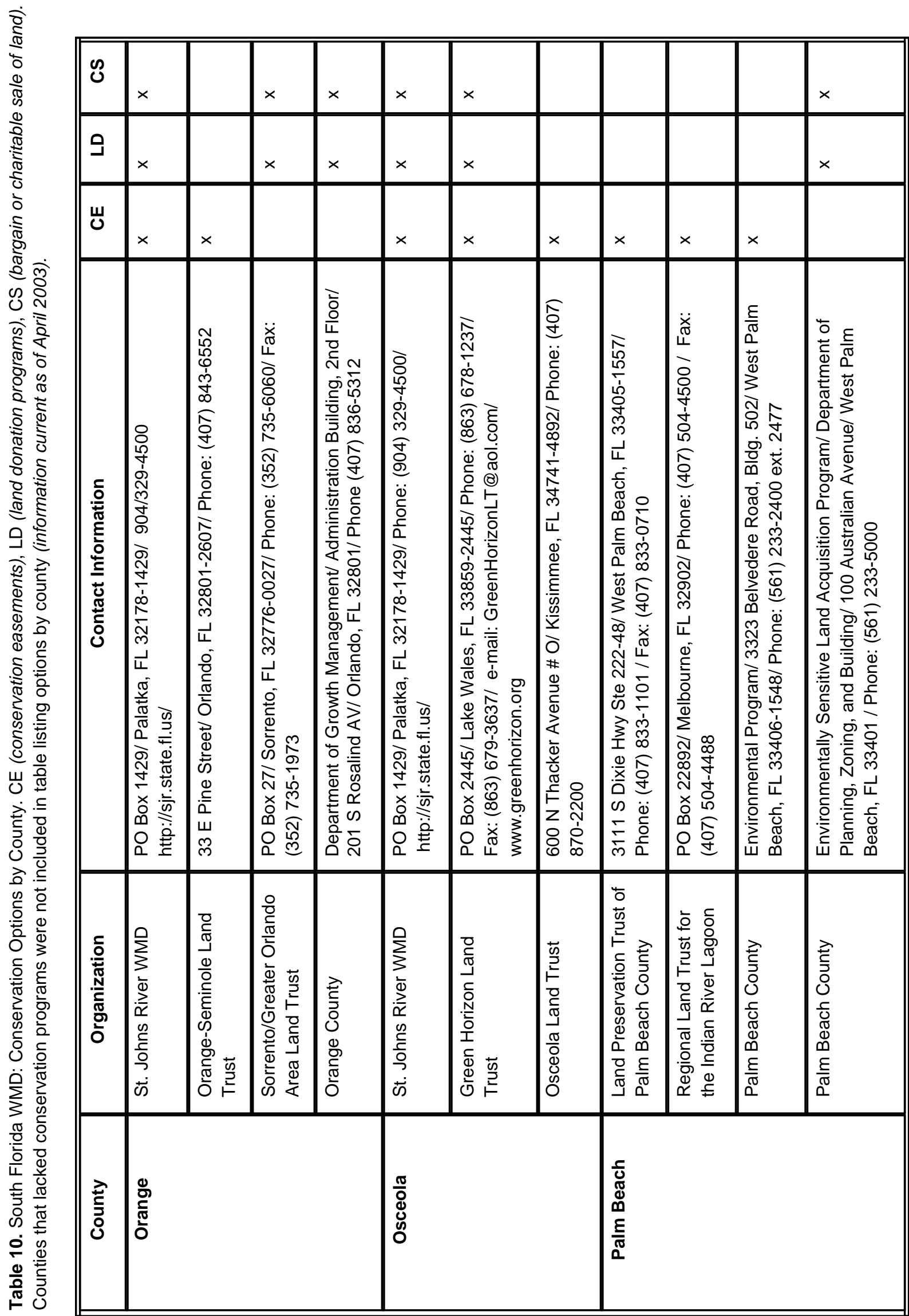




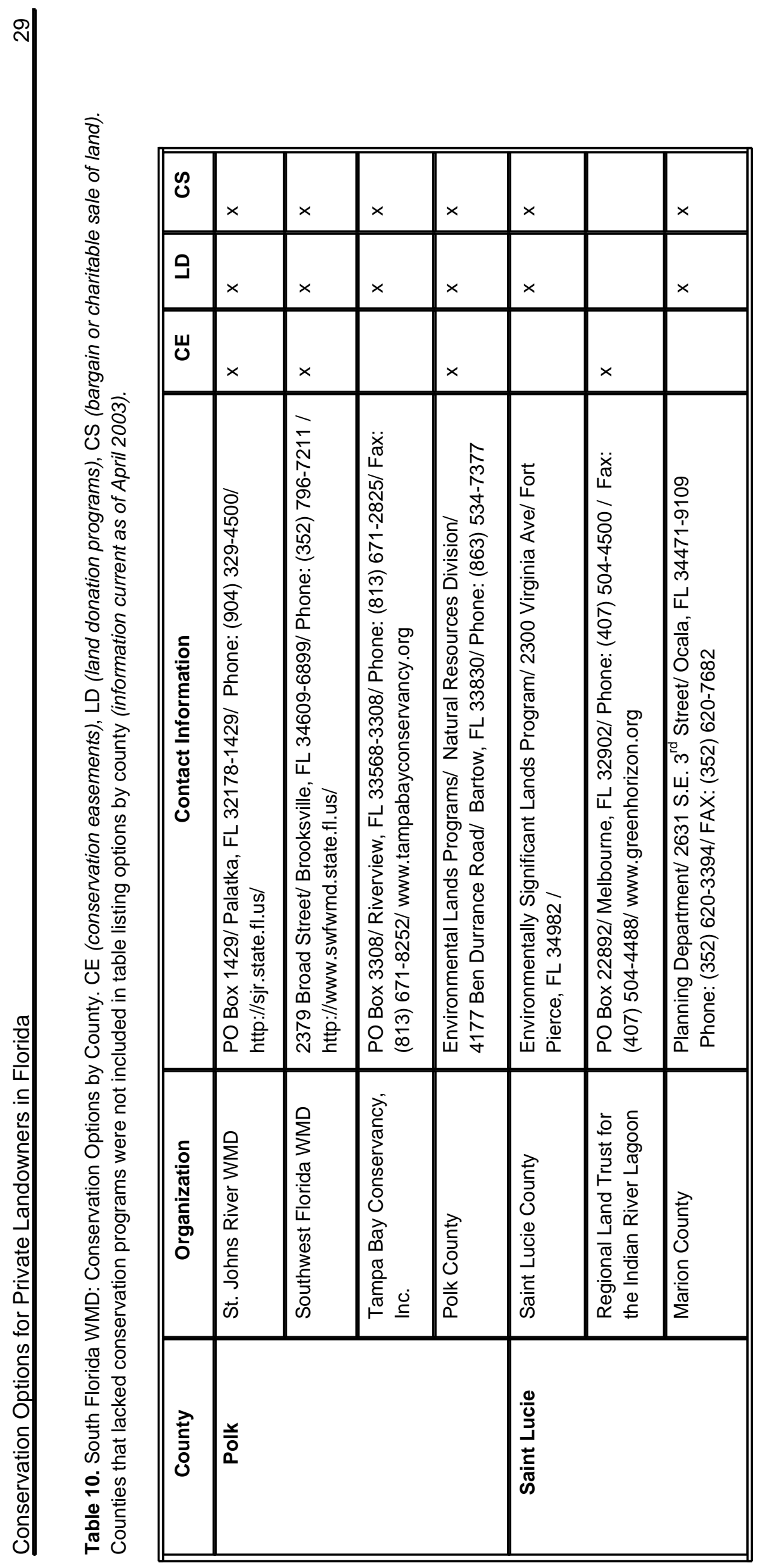

